Boston University School of Law

Scholarly Commons at Boston University School of Law

Faculty Scholarship

$11-2019$

\title{
Why Robert Mueller's Appointment As Special Counsel Was Unlawful
}

Gary S. Lawson

Boston Univeristy School of Law

Steven Calabresi

Northwestern University - Pritzker School of Law

Follow this and additional works at: https://scholarship.law.bu.edu/faculty_scholarship

Part of the Constitutional Law Commons, Criminal Law Commons, and the Legal History Commons

\section{Recommended Citation}

Gary S. Lawson \& Steven Calabresi, Why Robert Mueller's Appointment As Special Counsel Was Unlawful, in 95 Notre Dame Law Review 87 (2019).

Available at: https://scholarship.law.bu.edu/faculty_scholarship/583

This Article is brought to you for free and open access by Scholarly Commons at Boston University School of Law. It has been accepted for inclusion in Faculty Scholarship by an authorized administrator of Scholarly Commons at Boston University School of Law. For more information, please contact lawlessa@bu.edu. 


\title{
WHY ROBERT MUELLER'S APPOINTMENT AS SPEGIAL COUNSEL WAS UNLAWFUL
}

\author{
Steven G. Calabresi* E Gary Lawson**
}

Since 1999, when the independent counsel provisions of the Ethics in Government Act expired, the Department of Justice (DOJ) has had in place regulations providing for the appointment of "special counsels" who possess "the full power and independent authority to exercise all investigative and prosecutorial functions of any United States Attorney." Appointments under these regulations, such as the May 17, 2017 appointment of Robert S. Mueller to investigate the Trump campaign, are patently unlawful, for three distinct reasons.

First, all federal offices must be "established by Law," and there is no statute authorizing such an office in the DOJ. We conduct what we think is the first thorough examination of the statutes structuring the DOJ to show that the statutory provisions relied upon by the DOJ and lower courts for the appointment of special counsels over the past two decades do not-and even obviously do not-authorize the creation and appointment of special counsels at the level of United States Attorneys. They authorize the creation and appointment of special counsels to "assist" United States Attorneys, and they allow existing Senate-confirmed United States Attorneys to serve also as special counsels, but they do not remotely authorize the creation of the kind of special counsels represented by Robert Mueller who replace rather than assist United States Attorneys. United States v. Nixon, 418 U.S. 683 (1974), does not hold to the contrary, because no question was raised in that case about the validity of the independent counsel's appointment.

Second, even if one chooses to overlook the absence of statutory authority for the position, there is no statute specifically authorizing the Attorney General, rather than the President by and with the advice and consent of the Senate, to appoint such a special counsel. Under the Appointments Clause, inferior officers can be appointed by department heads only if Congress so directs by statute — and so directs specifically enough to overcome a clear-statement presumption in favor of presidential appointment and senatorial confirmation. No such statute exists for the special counsel.

(C) 2019 Steven G. Calabresi \& Gary Lawson. Individuals and nonprofit institutions may reproduce and distribute copies of this Article in any format at or below cost, for educational purposes, so long as each copy identifies the author, provides a citation to the Notre Dame Law Review, and includes this provision in the copyright notice.

* Clayton J. \& Henry R. Barber Professor, Northwestern Pritzker School of Law; Visiting Professor of Law, Fall 2013-18, Yale Law School; Co-Founder and Chairman of the Board of Directors of the Federalist Society. The views expressed herein are solely my own and not those of the Northwestern Pritzker School of Law, Yale Law School, or the Federalist Society.

** Philip S. Beck Professor of Law, Boston University School of Law. We are grateful to Josh Blackman, Paul Kamenar, and Seth Barrett Tillman for helpful comments, though they bear no responsibility for our analysis or conclusions. 
Third, the special counsel is, in all events, a superior rather than inferior officer, and thus cannot be appointed by any means other than presidential appointment and senatorial confirmation regardless of what any statutes purport to say. This is obviously true as a matter of original meaning, and it is even true as a matter of case law once one understands that neither Morrison v. Olson, 487 U.S. 654 (1988), nor Edmond v. United States, 520 U.S. 651 (1997), can plausibly be read to say that any person who is in any fashion subordinate to another executive official is an "inferior" officer. Such a reading of those decisions leads to the ludicrous result that there is only one noninferior officer in every federal department, which is a good reason not to read them that way.

There are surely times when special counsels are appropriate. Both statutes and the Constitution provide ample means for such appointments through the use of existing United States Attorneys with unimpeachable credentials and reputations for standing above politics. Any number of United States Attorneys have performed these functions with distinction. Statutes and the Constitution do not, however, permit the Attorney General to appoint a private citizen as a substitute United States Attorney under the title "special counsel." That is what happened on May 17, 2017. That appointment was unlawful, as are all of the legal actions that have flowed from it.

The D.C. Circuit's unreasoned February 26, 2019 opinion in In re Grand Jury Investigation upholding Mueller's appointment does not come to grips with any of these arguments. The panel decision asserts (falsely) that the issues were either waived by the party challenging the appointment or are readily resolved by Supreme Court precedent. If the latter claim was true, those precedents would cry out for clarification or reconsideration by the Court. But that latter claim is only even minimally plausible based on the most superficial skimming of the applicable precedents.

The statutory and constitutional structure of federal law enforcement is a serious matter, and one might have hoped that the federal courts—and the Department of Justice-would devote a bit more mental energy to that matter than they have thus far expended.

\section{INTRODUCTION}

On May 17, 2017, acting Attorney General Attorney General Rod J. Rosenstein, ${ }^{1}$ appointed former Federal Bureau of Investigation (FBI) Director Robert S. Mueller to be a special counsel for the United States Department of Justice. Mueller was ordered to investigate whether Donald Trump's 2016 presidential campaign illegally colluded with the government of Russia to influence the 2016 presidential election and to bring any appropriate

1 Rosenstein was acting Attorney General for those matters within the Department of Justice for which then-Attorney General Jeff Sessions recused himself. See Press Release, U.S. Dep't of Justice, Attorney General Sessions Statement on Recusal (Mar. 2, 2017), https://www.justice.gov/opa/pr/attorney-general-sessions-statement-recusal. We do not address here whether former Attorney General Sessions' recusal was necessary or appropriate under Department of Justice regulations regarding recusal. See 28 C.F.R. $§ 45.2$ (2018). 
prosecutions. $^{2}$ At the time of his appointment, Mr. Mueller was a private citizen not then employed by the Department of Justice. ${ }^{3}$

On March 22, 2019, nearly two years after his appointment, Mr. Mueller concluded his investigation and delivered a 488-page report to Attorney General William Barr. ${ }^{4}$ The report did not charge or recommend charging anyone with a crime involving contact with Russian officials or agents because "[t] he investigation did not establish . . . an agreement to commit any substantive violation of federal criminal law-including foreign-influence and campaign-finance laws." ${ }^{5}$ Nor did the investigation "yield evidence sufficient to sustain any charge that any individual affiliated with the Trump Campaign acted as an agent of a foreign principal ... subject to the direction or control of the government of Russia, or any official thereof." 6 The special counsel also investigated whether President Trump obstructed justice during the course of the investigation and "determined not to make a traditional prosecutorial judgment," and thus "did not draw ultimate conclusions about the President's conduct." 7 Attorney General Barr and Deputy Attorney General Rosenstein concluded that no prosecution for obstruction of justice was warranted. ${ }^{8}$ With that, the Justice Department investigation was closed, leaving the aftermath to the political arena.

Or so one might think. But before closing up shop, Special Counsel Mueller empaneled a grand jury, ${ }^{9}$ issued hundreds of subpoenas, ${ }^{10}$ indicted

2 See Order No. 3915-2017, Appointment of Special Counsel to Investigate Russian Interference with the 2016 Presidential Election and Related Matters (May 17, 2017), https://www.justice.gov/opa/press-release/file/967231/download [hereinafter Appointment Memo].

3 Mueller had joined the prominent law firm of WilmerHale in 2014. See Former Director of the FBI Robert Mueller III Joins WilmerHale, WiLmerHale (Mar. 24, 2014), https:// www.wilmerhale.com/en/insights/news/former-director-of-the-fbi-robert-mueller-iii-joinswilmerhale.

4 Robert S. Mueller III, U.S. Dep't of Justice, Report on the Investigation into Russian Interference in the 2016 Presidential Election (2019) [hereinafter Mueller REPORT], https://www.justice.gov/storage/report.pdf.

51 Mueller Report, supra note 4, at 181.

$6 \quad$ Id. at 183.

72 Mueller Report, supra note 4, at 182.

8 See Letter from William P. Barr, Att'y Gen., U.S. Dep't of Justice, to the Committee on the Judiciary (Mar. 24, 2019), https://judiciary.house.gov/sites/democrats.judiciary. house.gov/files/documents/AG\%20March\%2024\% 202019\%20Letter\%20to\%20House\% 20and\%20Senate\%20Judiciary\%20Committees.pdf.

9 See Spencer S. Hsu, Federal Grand Jury Working in Mueller Probe Is Extended, WASH. Post (Jan. 4, 2019), https://www.washingtonpost.com/local/legal-issues/federal-grandjury-working-in-mueller-probe-is-extended/2019/01/04/e480b364-105f-11e9-8938-5898adc 28fa2_story.html.

10 Some of those subpoenas have been the subject of motions to quash. See In re Grand Jury Investigation, 315 F. Supp. 3d 602 (D.D.C. 2018), aff'd, 916 F.3d 1047 (D.C. Cir. 2019); United States v. Concord Mgmt. \& Consulting LLC, 317 F. Supp. 3d 598 (D.D.C. 2018). 
at least thirty-three people and three companies, ${ }^{11}$ secured seven guilty pleas, ${ }^{12}$ and obtained convictions on eight counts in a criminal trial. ${ }^{13}$ During its two years of operation, the special counsel's office performed numerous acts with formal legal consequences, and many of those acts continue to have serious effects even after the investigation ceased.

All of those legally consequential acts were and are unlawful.

Robert Muller's appointment to be a special counsel was unlawful on both statutory and constitutional grounds. Congress has not authorized by law the position of special counsel to which Mueller was appointed; Congress has not by law vested in the Attorney General the power to appoint inferior officer special counsels; and the office to which Mueller has been appointed is not, in any event, an inferior office but is instead an office to which appointment requires presidential nomination and confirmation by the Senate. Every legal act that Robert Mueller has taken since May 17, 2017, is therefore null and void. ${ }^{14}$

We reach this conclusion while recognizing that there are times when it makes sense to use special counsels with a reputation for independence and integrity to investigate presidential or other high-level wrongdoing. In these cases, there is often reason to doubt whether the political appointees of the Department of Justice could conduct investigations with at least the appearance of objectivity. The creation of a special counsel to investigate high-level wrongdoing is fine in principle and may, on occasion, be commendable in practice. But, there are lawful and unlawful ways to go about creating a special counsel. In this instance, quite unfortunately, acting Attorney General Rod Rosenstein acted unlawfully in appointing private citizen Robert Mueller to be a special counsel to investigate President Trump's alleged collusion with Russia. We begin by explaining where Rosenstein went wrong.

The constitutionally_and, under present law, statutorily-correct way to appoint a freestanding special counsel is to ask one of the ninety-three existing Senate-confirmed U.S. Attorneys to take on the germane task of investigating presidential or other high-level wrongdoing. Most U.S. Attor-

11 Jesus Rodriguez \& Beatrice Jin, The Mueller Indictments So Far: Lies, Trolls, and Hacks, Politico (Dec. 7, 2018), https://www.politico.com/interactives/2018/interactive_mueller -indictments-russia-cohen-manafort/.

12 Jason Breslow, All the Criminal Charges to Emerge from Robert Mueller's Investigation, NPR (Dec. 9, 2018), https://www.npr.org/2018/12/09/643444815/all-the-criminal-charges-toemerge-so-far-from-robert-muellers-investigation.

13 See Matt Zapotosky et al., Manafort Convicted on 8 Counts; Mistrial Declared on 10 Others, Wash. Post (Aug. 21, 2018), https://www.washingtonpost.com/world/nationalsecurity/manafort-jury-suggests-it-cannot-come-to-a-consensus-on-a-single-count/2018/08/ 21/a2478ac0-a559-11e8-a656-943eefab5daf_story.html.

14 We leave for another time whether any of his actions can be saved by the de facto officer doctrine. The short answer is no. For reasons that one of us has explored at great length elsewhere, the de facto officer doctrine cannot save actions where the office itself is unlawful and there is thus more than a mere technical defect in the appointment process. See Gary Lawson \& Guy Seidman, The Hobbesian Constitution: Governing Without Authority, 95 Nw. U. L. Rev. 581, 595-96 (2001). 
neys are career prosecutors whose political ties tend to be to their home-state senators and not to the President who nominated them. Many of them have exemplary reputations for independence and integrity, as well as years of prosecutorial experience, often working for both Democratic and Republican administrations. They are therefore Senate-confirmed officials of exemplary independence and integrity who are constitutionally and statutorily qualified to investigate the President of the United States or any other highlevel governmental official or presidential friend.

Four U.S. Attorneys who served as special counsels or performed similar functions without the formal appointment or title in the last twenty years prove this point. On December 30, 2003, Patrick Fitzgerald, who was then the U.S. Attorney for the Northern District of Illinois, was lawfully appointed $^{15}$ by the then-acting Attorney General to investigate the Valerie Plame leak affair, which arose within the jurisdiction of the District of Columbia District Court. ${ }^{16}$ Mr. Fitzgerald, who was a Senate-confirmed officer of the United States, prosecuted and secured the conviction of Vice President Richard Cheney's Chief of Staff, Scooter Libby, in the District of Columbia District Court. ${ }^{17}$ Since Libby did not implicate Vice President Cheney, Mr. Fitzgerald's investigation stopped there. It should be added that Fitzgerald had a powerful reputation for independence and integrity, having indicted and secured the conviction for bribery of the sitting governor of Illinois. ${ }^{18}$ Everyone had complete confidence in Fitzgerald's investigation.

Three other Senate-confirmed U.S. Attorneys, with reputations for independence like Mr. Fitzgerald's, have constitutionally been asked by the Attorney General to investigate high-level wrongdoing in recent years. The Senate-confirmed U.S. Attorney in Maryland, Rod Rosenstein (ironically), who had served under both Presidents Bush and Obama, was asked by President Obama's Attorney General, Eric Holder, to investigate and prosecute General James Cartwright, a former Vice Chairman of the Joint Chiefs of

15 The first person appointed under the 1999 Reno Regulations was former Senator John Danforth, who was appointed in September 1999 to investigate the 1993 tragedy in Waco, Texas, involving the Justice Department's raid on a Branch Davidian compound that resulted in seventy-six deaths. See Pete Yost, Danforth to Head Waco Inquiry, Associated Press (Sept. 8, 1999), https://www.apnews.com/ee472a93fca37920411clad533e81ee1; Waco Siege, History (Dec. 19, 2017), https://www.history.com/topics/1990s/waco-siege. For the reasons given in this Article, that appointment was unlawful.

16 See Ashcroft Recused from Leak Investigation, United Press Int'L (Dec. 30, 2003), https:/ /www.upi.com/Top_News/2003/12/30/Ashcroft-recused-from-leak-investigation/ $48811072812243 /$.

17 See Andrew Glass, 'Scooter' Libby Convicted of Perjury, March 6, 2007, Politico (Mar. 6, 2014), https://www.politico.com/story/2014/03/this-day-in-politics-104300. President Trump pardoned Mr. Libby, more than a decade after his conviction, on April 13, 2018. See Press Release, White House, Statement from the Press Secretary Regarding the Pardon of I. "Scooter" Lewis Libby (Apr. 13, 2018), https://www.whitehouse.gov/briefings-state ments/statement-press-secretary-regarding-pardon-scooter-lewis-libby/.

18 See Annie Sweeney, Fitzgerald: 'The Vindication Is to the People, ' Chr. Trib. (June 27, 2011), https://www.chicagotribune.com/nation-world/ct-xpm-2011-06-27-ct-met-bla gojevich-fitzgerald-06-20110627-story.html. 
Staff, for leaking information to reporters. ${ }^{19}$ General Cartwright pled guilty to this charge, ${ }^{20}$ and he was later pardoned. ${ }^{21}$ This is a second example of the special counsel system working as it should.

In November 2017, then-Attorney General Jeff Sessions asked the Senate-confirmed U.S. Attorney for Utah, John W. Huber, who had held office both under President Obama and President Trump, to investigate alleged wrongdoing by the FBI in the District of Columbia District Court's jurisdiction. ${ }^{22}$ Mr. Huber took on this germane task, in addition to his duties as the U.S. Attorney for Utah. There is every reason to believe that U.S. Attorney Huber will conduct this investigation thoroughly and in a nonpartisan way.

Finally, at some point in the spring of 2019, Attorney General William Barr tasked John Durham, the U.S. Attorney for Connecticut, with investigating the origins of the Department of Justice's probes of the Trump campaign in $2016 .{ }^{23}$

All of these investigations and prosecutions of high-level wrongdoing were totally constitutional, legal, and appropriate, and they were (or are being) conducted by prosecutors of the highest degree of independence and integrity.

Our reading of the relevant statutes and the Appointments Clause would allow a future Attorney General to ask any of the existing Senate-confirmed U.S. Attorneys to serve as a special counsel or perform equivalent functions in a case of alleged presidential or other high-level wrongdoing. That arrangement is perfectly constitutional and statutorily authorized. Among that group one can surely find someone with the intellect, integrity, and character to be a special counsel as well as a United States Attorney. There are one hundred United States senators who play key roles in the selection of the (at present) ninety-three United States Attorneys, so there will always be some talented and independent-minded United States Attorneys who are not friends or acquaintances of the President who could be tapped to investigate the President. In fact, many United States Attorneys, such as John Huber and Rod Rosenstein, serve or have served both Democratic and Republican administrations.

19 See Josh Gerstein, Holder Names Leak Probe Prosecutors, Politico (June 8, 2012), https://www.politico.com/story/2012/06/holder-names-2-prosecutors-to-probe-leaks077228 .

20 See Press Release, U.S. Dep't of Justice, Former Vice Chairman of the Joint Chief of Staff Pleads Guilty to Federal Felony in Leak Investigation (Oct. 17, 2016), https://www. justice.gov/opa/pr/former-vice-chairman-joint-chiefs-staff-pleads-guilty-federal-felony-leakinvestigation.

21 See Pardons Granted by President Barak Obama (2009-2017), U.S. DeP'T Just., https:// www.justice.gov/pardon/obama-pardons (last updated July 11, 2018).

22 See Jeff Mordock, John Huber, Who Will Investigate the FBI Is a Special Counsel in Every Way but Name, WAsh. Times (Apr. 1, 2018), https://www.washingtontimes.com/news/20 18/apr/1/john-huber-us-attorney-leading-fbi-investigation-s/.

23 See Brooke Singman, Who Is John Durham? Prosecutor Tapped for Russia Proble Inquiry Known as 'Aggressive, Tireless, and Fair,' Fox News (May 15, 2019), https://www.foxnews. $\mathrm{com} /$ politics/who-is-john-durham-prosecutor-russia-probe. 
What the Attorney General cannot lawfully do under the Constitution and current statutes, however, is pluck a private citizen like Robert Mueller out of retirement, create a putatively inferior office of special counsel to investigate the President for illegal collusion with Russia during the 2016 presidential campaign, and then appoint that private citizen to be a special counsel. First, such an action violates the current statutes enacted by Congress for the structure of the Department of Justice. Those statutes do authorize the appointment of counsels, but those counsels must "assist" 24 United States Attorneys. The office held by Mueller replaced rather than assisted United States Attorneys, and there is no legal authority for such an office. For years, the Department of Justice has mindlessly been relying on purported statutory authority for U.S. Attorney-replacing special counsels that simply does not exist. We will demonstrate this point in detail. ${ }^{25}$

Second, such an action violates the Appointments Clause, which provides:

[The President] shall nominate, and by and with the Advice and Consent of the Senate, shall appoint Ambassadors, other public Ministers and Consuls, Judges of the supreme Court, and all other Officers of the United States, whose Appointments are not herein otherwise provided for, and which shall be established by Law: but the Congress may by Law vest the Appointment of such inferior Officers, as they think proper, in the President alone, in the Courts of Law, or in the Heads of Departments. ${ }^{26}$

The default rule for federal appointments is nomination by the President and confirmation by the Senate, and that never occurred with Special Counsel Mueller. Robert Mueller purported to be an inferior officer of the United States, ${ }^{27}$ but Congress has not by law vested the power to appoint inferior officers in the Attorney General. The Appointments Clause is as clear as day that inferior officers can only be appointed by any means other than presidential nomination and senatorial consent where Congress by law expressly authorizes the President, the courts of law, or the heads of departments to appoint them. This amounts to a constitutionally prescribed clear statement rule. ${ }^{28}$ We prove in this Article beyond a reasonable doubt that the Attorney General has no statutory authority to create and appoint inferior officer special counsels who do not assist a United States Attorney to whom they are subordinate. We canvas every single provision of Title 28 bearing on the Department of Justice, and there is quite simply no statute that vests in the Attorney General the power to appoint such inferior officers.

In contrast to the organic statute of the Department of Justice, the organic statutes of the Agriculture, Education, Health and Human Services, and Transportation Departments do contain clear inferior officer appointment power clauses. Thus, the Agriculture Secretary "may appoint such officers and

2428 U.S.C. $\$ 543$ (2012).

25 See infra Part II.

26 U.S. Const. art. II, § 2, cl. 2.

27 See 2 Mueller Report, supra note 4, at 175.

28 See, e.g., Gregory v. Ashcroft, 501 U.S. 452, 460-61 (1991). 
employees ... and such experts, as are necessary to execute the functions vested in him";29 the Education Secretary "is authorized to appoint and fix the compensation of such officers and employees, including attorneys, as may be necessary to carry out the functions of the Secretary and the Department"; 30 the Health and Human Services Secretary "is authorized to appoint and fix the compensation of such officers and employees"; ${ }^{31}$ and the Transportation Secretary "may appoint and fix the pay of officers and employees of the Department of Transportation." 32 For good measure, the Administrative Procedure Act says that "[e]ach agency shall appoint as many administrative law judges as are necessary for [hearing and deciding cases]." 33 And for the coup de grace, Congress gave the Attorney General power to "appoint such additional officers and employees as he deems necessary" 34 specifically for the Bureau of Prisons but not more broadly for other units of the Department of Justice.

Why did Congress choose to give general inferior officer appointment power to the Secretaries of Agriculture, Education, Health and Human Services, and Transportation, but not to the Attorney General (except in the limited context of the Bureau of Prisons)? Probably because of the unique threat that a bad Attorney General could pose to civil liberties, to the states, which United States senators represent, and to the separation of powers. A bad Attorney General today (in 2019) could appoint a special counsel to probe the lives of Democratic Minority Leader Charles Schumer or of House Speaker Nancy Pelosi, looking for dirt. One shudders to think what abuses might have been condoned in the McCarthy era if Attorneys General had unlimited and unchecked power to create inferior officer special counsels.

Federal prosecutors are fearsome creatures. Attorney General Robert Jackson, speaking to the Second Annual Conference of United States Attorneys on April 1, 1940, said the following:

It would probably be within the range of that exaggeration permitted in Washington to say that assembled in this room is one of the most powerful peace-time forces known to our country. The prosecutor has more control over life, liberty, and reputation than any other person in America. His discretion is tremendous. He can have citizens investigated and, if he is that kind of person, he can have this done to the tune of public statements and veiled or unveiled intimations. Or the prosecutor may choose a more subtle course and simply have a citizen's friends interviewed. The prosecutor can order arrests, present cases to the grand jury in secret session, and on the basis of his one-sided presentation of the facts, can cause the citizen to be indicted and held for trial. He may dismiss the case before trial, in which case the defense never has a chance to be heard. Or he may go on with a

297 U.S.C. $\$ 610$ (a) (2012).

3020 U.S.C. $\$ 3461$ (a) (2012).

3142 U.S.C. $\$ 913$ (2012).

3249 U.S.C. $\$ 323(\mathrm{a})(2012)$.

335 U.S.C. $\$ 3105$ (2012). Administrative law judges are constitutional officers. See

Lucia v. SEC, 138 S. Ct. 2044 (2018).

3418 U.S.C. $\$ 4041$ (2012). 
public trial. If he obtains a conviction, the prosecutor can still make recommendations as to sentence, as to whether the prisoner should get probation or a suspended sentence, and after he is put away, as to whether he is a fit subject for parole. While the prosecutor at his best is one of the most beneficent forces in our society, when he acts from malice or other base motives, he is one of the worst.

These powers have been granted to our law-enforcement agencies because it seems necessary that such a power to prosecute be lodged somewhere. This authority has been granted by people who really wanted the right thing done-wanted crime eliminated-but also wanted the best in our American traditions preserved.

Because of this immense power to strike at citizens, not with mere individual strength, but with all the force of government itself, the post of Federal District Attorney from the very beginning has been safeguarded by presidential appointment, requiring confirmation of the Senate of the United States. You are thus required to win an expression of confidence in your character by both the legislative and the executive branches of the government before assuming the responsibilities of a federal prosecutor. ${ }^{35}$

Congress did not create the Department of Justice in 1789 along with the Department of State, the Department of the Treasury, the Department of War, and the Post Office. The Judiciary Act of 1789 created an office of Attorney General of the United States (but no Department of Justice), and sixteen District Attorneys, now called United States Attorneys, who had to be nominated by the President and confirmed by the Senate. ${ }^{36}$ Permanent United States Attorneys have always, throughout all 230 years of American history, required nomination by the President and confirmation by the Senate. The United States Department of Justice was not created until 1870, ${ }^{37}$ after the Civil War, and even then, Congress has always been jealous of the powers it delegates to the DOJ for civil rights reasons, for federalism reasons, and for separation of powers reasons. Those concerns are simply not as salient with the Departments of Agriculture, Education, Health and Human Services, and Transportation.

By blundering ahead on May 17, 2017, and creating an inferior special counsel who was not subordinate to a U.S. Attorney, which he had no power to create, and then appointing a private citizen to that office, acting Attorney General Rod Rosenstein violated the Constitution. Moreover, none of the statutes he cited as granting him the authority to create this particular special counsel actually granted him that authority. Nor do any statutes that he did not cite contain the necessary authority. Congress has not by law delegated to the Attorney General the power to create inferior officer special coun-

35 Robert H. Jackson, Att'y Gen., U.S. Dep't of Justice, Address at the Second Annual Conference of United States Attorneys: The Federal Prosecutor (Apr. 1, 1940), https:// www.justice.gov/sites/default/files/ag/legacy/2011/09/16/04-01-1940.pdf (emphasis added).

36 See Judiciary Act of 1789 , ch. 20, § 35, 1 Stat. 73, 92-93.

37 See About DOJ, U.S. DeP'T Just., https://www.justice.gov/about (last visited Sept. 26, 2019). 
sels-or inferior officer Solicitors General or inferior officer United States Attorneys-who do anything more than "assist" United States Attorneys on specific matters calling for outside expertise. Rosenstein broke the law when he appointed Robert Mueller.

On February 26, 2019, the Court of Appeals for the District of Columbia Circuit upheld the legality of Mueller's appointment in a case challenging Mueller's authority to issue a subpoena. ${ }^{38}$ The D.C. Circuit's brief, unreasoned opinion does not come to grips with any of the arguments that we present-or, for that matter, with any of the arguments that were presented to the court. The panel decision asserts (falsely) that the issues discussed in this article were either waived by the party challenging Mueller's appointment or are readily resolved by Supreme Court precedent. If Supreme Court precedents truly foreclosed the issues that we are raising, those precedents would cry out for clarification or reconsideration by the Supreme Court. But the D.C. Circuit relied on a remarkably superficial skimming of the applicable precedents, which, as we later demonstrate in detail, do not in fact resolve that issues that we are raising here. It is almost as though the D.C. Circuit did not want to look behind the curtain. The statutory and constitutional structure of federal law enforcement, however, is a serious matter. One might hope that the federal courts-and the Department of Justicewould devote a bit more mental energy to that matter than they have thus far expended.

This Article will proceed in the following Parts. Part I briefly discusses the Mueller appointment and the authority claimed to make it. Part II dissects the statutes, which it is claimed support an Attorney General power to create inferior officers who do not assist U.S. Attorneys, and demonstrates that none of those statutes does any such thing. That Part also explains that the legal question raised here was not raised, litigated, briefed, or decided in the Watergate Tapes Case, United States $v$. Nixon, ${ }^{39}$ so that case cannot serve as precedent to support Rosenstein's actions. Part III argues that the Constitution does not permit the appointment of an officer, unconfirmed by the Senate, with Robert Mueller's range of authority. This Article concludes with recommendations of how to amend the Department of Justice's regulations on the appointment of special counsels so as to render them lawful in future cases.

Whatever one thinks of Robert Mueller, Donald Trump, Paul Manafort, Michael Flynn, James Comey, or any of the other dramatis personae who have filled headlines for the past few years, law matters. Robert Mueller's investigation, and the legal action that has resulted from it, was statutorily and constitutionally unlawful. There are ways consistent, both with existing statutes and with the Constitution, for the Department of Justice to create a special counsel, and those methods have been employed on occasion-and are actually being employed in some cases as we write this Article. But the

38 See In re Grand Jury Investigation, 916 F.3d 1047, 1056 (D.C. Cir. 2019).

39418 U.S. 683 (1974). 
appointment by the Attorney General of a private citizen to a position that amounts to a supercharged U.S. Attorney is not one of them.

\section{The Appointment of Robert Mueller}

As we noted at the beginning of this Article, on May 17, 2017, U.S. Deputy Attorney General Rod J. Rosenstein, in the capacity of acting Attorney General, ${ }^{40}$ appointed former FBI Director, and at that time private WilmerHale lawyer, Robert S. Mueller to be a special counsel for the Department of Justice. Mueller's charge as special counsel was to

conduct the investigation confirmed by then-FBI Director James B. Comey in testimony before the House Permanent Select Committee on Intelligence on March 20, 2017, including:

(i) any links and/or coordination between the Russian government and individuals associated with the campaign of President Donald Trump; and

(ii) any matters that arose or may arise directly from the investigation; and

(iii) any other matters within the scope of 28 C.F.R. $§ 600.4(a){ }^{41}$

The special counsel was "authorized to prosecute federal crimes arising from the investigation of these matters." 42

For two years after his appointment, Mueller's investigation consumed United States law and politics. The special counsel's office assembled a team of more than a dozen lawyers and more than a dozen supporting staff members, with expenditures exceeding $\$ 25$ million. ${ }^{43}$ As we noted in our introduction, Mueller as special counsel empaneled a grand jury, ${ }^{44}$ issued numerous subpoenas, ${ }^{45}$ indicted at least thirty-three people and three companies, ${ }^{46}$ secured seven guilty pleas, ${ }^{47}$ and obtained convictions on eight counts in a criminal trial. ${ }^{48}$

40 It is actually a serious question whether the Attorney General's recusal made Deputy Attorney General Rosenstein the acting Attorney General. We do not address that question in this Article. See In Re Grand Jury Investigation, 916 F.3d 1047, 1054-56 (D.C. Cir. 2019).

41 Appointment Memo, supra note 2.

$42 I d$.

43 See Matt Zapotosky, Latest Expenditure Data Shows Mueller Probe Cost About \$25 Million Through September, WAsH. Post (Dec. 14, 2018), washingtonpost.com/world/national-secur ity/latest-expenditure-data-shows-mueller-probe-cost-about-25-million-through-september/ 2018/12/14/ae00f216-ffe5-11e8-ad40-cdfd0e0dd65a_story.html.

44 Hsu, supra note 9.

45 Some of those subpoenas have been the subject of motions to quash. See In re Grand Jury Investigation, 315 F. Supp. 3d 602 (D.D.C. 2018), aff'd, 916 F.3d 1047 (D.C. Cir. 2019); United States v. Concord Mgmt. \& Consulting LLC, 317 F. Supp. 3d 598 (D.D.C. 2018).

46 Rodriguez \& Jin, supra note 11.

47 Breslow, supra note 12.

48 Zapotosky et al., supra note 13. 
All of this prosecutorial activity has been unlawful. Mr. Mueller was fully capable of writing a report on any matter he wished to submit to the Department of Justice ${ }^{49}$ just as we are fully capable of writing a law review Article and submitting it to anyone who will read it. But Mr. Mueller had no more legal authority to empanel grand juries and issue subpoenas to gather information for that report, much less to issue indictments and obtain guilty pleas and convictions, than we do. The entire Mueller investigation has been a legal nullity since the get-go.

Some of the legal problems with the Mueller investigation are similar to the problems that plagued independent counsels under the Ethics in Government $\mathrm{Act}^{50}$ from 1978 to 1999 , most notably that both Mueller and independent counsels, such as Alexia Morrison, were appointed using procedures appropriate for inferior officers of the United States rather than by presidential nomination and senatorial confirmation, as the Constitution requires for the appointment of superior officers. ${ }^{51}$ The independent counsel appointment provisions were famously upheld as constitutional by the Supreme Court in 1988 in Morrison v. Olson. ${ }^{52}$ We thought then, and we think today, as does a growing number of legal observers and jurists, that Morrison $v$. Olson was wrongly decided, and we believe that history has to some extent vindicated, and will increasingly vindicate as time goes on, that position. Justice Scalia's dissenting opinion in Morrison ${ }^{53}$ is already a classic that overshadows the majority opinion, much like Justice Curtis's dissenting opinion in Dred Scott v. Sandford ${ }^{54}$ Justice Harlan's dissenting opinion in Plessy v. Ferguson, ${ }^{55}$ and Justice Holmes's dissenting opinion in Lochner v. New York. ${ }^{56}$ But even if one accepts Morrison v. Olson as good law, Mueller's appointment as special counsel is still unconstitutional. The nature and scope of Mueller's charge shows him to be a superior rather than inferior officer even under the (erroneous) standard of Morrison $v$. Olson. And as a matter of original meaning, Mueller is obviously a superior rather than an inferior officer and therefore can lawfully act only if appointed by the President with the advice and consent of the Senate. We explain all of this in Part III of this Article.

Before reaching that constitutional question, however, we first explore an even more basic problem with Mueller's appointment: there was and is no

49 See 28 C.F.R. $\$ 600.8$ (c) (2019) ("At the conclusion of the Special Counsel's work, he or she shall provide the Attorney General with a confidential report explaining the prosecution or declination decisions reached by the Special Counsel.").

50 Ethics in Government Act of 1978, Pub. L. No. 95-521, 92 Stat. 1824.

51 We use the term "superior officer" rather than the more common term "principal officer," because the former is descriptively accurate while the latter is not. Enormous mischief has resulted from careless use of the constitutional term "principal officer." We explain all of this in some detail later in this Article. See infra subsection III.B.1.

52487 U.S. 654 (1988).

53 See id. at 697 (Scalia, J., dissenting).

5460 U.S. (19 How.) 393, 564 (1857) (Curtis, J., dissenting), superseded by constitutional amendment, U.S. Const. amend. XIV.

55163 U.S. 537, 552 (1896) (Harlan, J., dissenting).

56198 U.S. 45, 74 (1905) (Holmes, J., dissenting). 
statutory authority for his office and appointment. All offices in the government of the United States that are not constitutionally mandated must be created by law. There is, quite simply, no law creating or authorizing the creation of Mueller's office, although there was a law (albeit an unconstitutional one) creating the Office of Independent Counsel from 1978 to 1999. The current special counsel framework is the creature of regulations promulgated by former Attorney General Janet Reno just before the Ethics in Government Act expired in 1999 without renewal by Congress. ${ }^{57}$ A regulation, however, cannot create an office that is going to be filled by a constitutional "Officer of the United States" that is not authorized by statute, and in the absence of the independent counsel statute, the statutes creating and defining the Department of Justice simply do not authorize the creation and appointment of special counsels such as Mueller. To be sure, those statutes do authorize the creation and appointment of certain kinds of special counsels, but those counsels must "assist" 58 United States Attorneys, which Mueller did not. His position was a freestanding office within the Department of Justice, and he wielded the full powers of any United States Attorney. Not only does that make Mueller a superior officer, as we will show in Part III, it also places his office outside the bounds of the statutes establishing the contours of the Department of Justice, as we will show in Part II.

Remarkably, we do not believe that anyone has previously taken a careful look at the statutory authorization for special counsels within the Department of Justice. We do so here. We also in Part II closely examine the cases that have generally taken by lower courts as establishing the legality of the office of special counsel. Even if one believes (as we do not) that caselaw can trump statutory language, those cases simply do not hold that there is statutory authorization for Mueller's appointment as special counsel. The language in those cases used by the government to support that appointment is dicta-and particularly ill-considered dicta-on issues that were never raised, briefed, litigated, or decided. Apart from a few unpersuasive, and in some cases poorly reasoned, district court opinions issued in $2018^{59}$ and one brief and unreasoned D.C. Circuit opinion issued in early $2019^{60}$ that rely on these inapposite precedents, there is no judicial resolution of the statutory questions that we raise in Part II.

\section{No Statute Authorizes the Appointment of a Special Counsel with Robert Mueller's Range of Authority}

In Part III, we will explain why Robert Mueller was not, by constitutional standards, an inferior officer who can be appointed to office without presi-

57 See Office of Special Counsel, 64 Fed. Reg. 37,038 (July 9, 1999) (codified at 28 C.F.R. $\$ \S 600.1-600.10$ (2019)) [hereinafter Reno Regulations].

5828 U.S.C. $\$ 543$ (2012).

59 See In re Grand Jury Investigation, 315 F. Supp. 3d 602 (D.D.C. 2018) (poorly reasoned), aff'd, 916 F.3d 1047 (D.C. Cir. 2018); United States v. Concord Mgmt. \& Consulting LLC, 317 F. Supp. 3d 598 (D.D.C. 2018) (unpersuasive).

$60 \quad$ See In re Grand Jury Investigation, 916 F.3d 1047. 
dential nomination and senatorial confirmation. But even if he was an inferior officer who could properly be appointed by a department head, such as the Attorney General, his appointment by the (acting) Attorney General would still be invalid because it was not authorized by statute-and not authorized in two distinct ways. First, the office itself was not created by or pursuant to a statute. Second, even if one can somehow manufacture statutory authorization for the position, Robert Mueller's appointment to that office by a department head, rather than by the President and the Senate, was not specifically prescribed by statute, as it must be to permit appointment of an officer by any means other than presidential nomination and senatorial confirmation. ${ }^{61}$ As a matter of straightforward statutory interpretation, the creation of Mueller's office, his appointment to that office, and therefore his criminal investigation, went forward without legal authority.

\section{A. No Statute Authorizes the Creation of a Special Counsel with Robert Mueller's Range of Authority}

The Constitution itself creates very few positions in the federal government. It creates the Congress, consisting of "a Senate and House of Representatives," ${ }^{62}$ the presidency and the vice presidency, ${ }^{63}$ a Supreme Court with a Chief Justice, ${ }^{64}$ and that is all. The Constitution assumes that there will be "Ambassadors," 65 "other public Ministers and Consuls," 66 federal judges other than the Chief Justice, ${ }^{67}$ and heads of executive "Departments" 68 (and specifically a "Treasury") ${ }^{69}$ but it does not directly create any of those positions. Instead, the Constitution commits the power to create federal offices to Congress under the Necessary and Proper Clause, ${ }^{70}$ which gives Congress power " $[\mathrm{t}] \mathrm{o}$ make all Laws which shall be necessary and proper for carrying into Execution the foregoing Powers, and all other Powers vested by this Con-

61 A third potential problem is whether Jeff Sessions, notwithstanding his recusal, was still the department head for Appointments Clause purposes when Mueller was appointed. We do not address that problem in this Article.

62 U.S. Const. art. I, § 1.

63 See id. art. II, $§ 1$, cl. 1 .

64 See id. art. III, $\S 1$. There must be at least one member of the Supreme Court, titled the Chief Justice, in order to preside over impeachment trials involving the President. See id. art. I, $\S 3$, cl. 6 .

$65 I d$. art. II, $\S 2$, cl. 2.

$66 I d$.

67 Id. art. I, § 8, cl. 9; id. art. II, § 2, cl. 2; id. art. III, § 1.

$68 I d$. art. II, $\$ 2$, cl. 2

69 Id. art. I, § 9, cl. 7.

70 See E. Garrett West, Note, Congressional Power over Office Creation, 128 Yale L.J. 166, 177-83 (2018). There were some suggestions at the Constitutional Convention that the Constitution be written to create specific offices, but those suggestions were not adopted. See id. at 170 n.8. 
stitution in the Government of the United States or in any Department or Officer thereof."71

A law creating offices to carry out executive functions is the quintessential law "necessary and proper for carrying into Execution" federal powers. Indeed, James Madison and Charles Pinckney proposed making this application of the Necessary and Proper Clause explicit by seeking to "insert between 'laws' and 'necessary' 'and establish all offices[,]' it appearing to them liable to cavil that the latter was not included in the former."72 An allstar chorus of Gouverneur Morris, James Wilson, John Rutledge, and Oliver Ellsworth insisted "that the amendment could not be necessary," and it was voted down 9-2.73 History has vindicated the chorus and the Convention vote; no one from 1789 onward has ever contested Congress's clearly enumerated power to create federal offices under the Necessary and Proper Clause.

More than this, Congress has the exclusive constitutional power to create federal offices. The Constitution does not give the President or the heads of executive departments the power to create any offices and to appoint any officers that they deem appropriate for any purpose. Instead, it requires that Congress first create all offices to which federal officers, superior or inferior, can be appointed. Elbridge Gerry at the Constitutional Convention sought to make this explicit by adding "that no officer shall be app[ointe]d but to offices created by the Constitution or by law."74 A 6-5 majority rejected the amendment as "unnecessary." ${ }^{5}$ The majority was correct, for two separate reasons. First, no federal institution other than Congress has any enumerated power to create offices. Second, the Constitution textually establishes congressional exclusivity through the Appointments Clause, which provides for the appointment of "Ambassadors, other public Ministers and Consuls, Judges of the supreme Court, and all other Officers of the United States, whose Appointments are not herein otherwise provided for, and which shall be established by Law." 66 The addition of the emphasized phrase in the Appointments Clause was deliberate. On September 15, 1787, "[a]fter 'Officers of the U.S. whose appointments are not otherwise provided for,' were added the words 'and which shall be established by law." 77 The "law" that establishes the office must be a statute; a regulation or executive (or judicial)

71 U.S. Const. art. I, $\S 8$, cl. 18. The founding generation called this provision the "Sweeping Clause," see Gary Lawson \& Patricia B. Granger, The "Proper" Scope of Federal Power: A Jurisdictional Interpretation of the Sweeping Clause, 43 Duke L.J. 267, 270-71 (1993), and that label was dominant into the early twentieth century. We use (one of us reluctantly) the modern label of "the Necessary and Proper Clause," on the theory that it will be more familiar to readers.

722 The Records of the Federal Convention of 1787, at 345 (Max Farrand ed., 1911) [hereinafter Records of the Federal Convention].

73 Id.

74 Id. at 550 .

75 Id

76 U.S. Const. art. II, § 2, cl. 2 (emphasis added).

772 Records of the Federal Convention, supra note 72, at 628. 
order does not constitute the kind of "law" that can create an office under the Appointments Clause. ${ }^{78}$ Indeed, the Constitution consistently uses the terms "law" and "laws," when otherwise unqualified, to mean statutes. ${ }^{79}$ If there is no establishment of an office by statute, there is no office to which someone can be appointed. ${ }^{80}$

The offices that make up the Department of Justice are identified in the statutes establishing and defining the contours of that Department. The Department of Justice was created on June 22, 1870.81 Its current structure, as provided by statute, includes an Attorney General ${ }^{82}$ in whom is vested vir-

78 See Seth Barrett Tillman, Why Our Next President May Keep His or Her Senate Seat: A Conjecture on the Constitution's Incompatibility Clause, 4 Duke J. Const. L. \& Pub. Pol'y SidebAR 1, 20-22 (2009); West, supra note 70, at 177-83; Limitations on Presidential Power to Create a New Executive Branch Entity to Receive and Administer Funds Under Foreign Aid Legislation, 9 Op. O.L.C. 76, 77-78 (1985) [hereinafter Limitations on Presidential Power].

79 See Gary Lawson \& Christopher D. Moore, The Executive Power of Constitutional Interpretation, 81 Iowa L. REv. 1267, 1315 (1996). Occasionally, those terms are qualified, as in the reference to "Offenses against the Law of Nations," see U.S. Const. art. I, $\$ 8$, cl. 10, or to the "Courts of Law." Id. art. II, § 2, cl. 2. But when used alone, "laws" consistently means statutes. See Lawson \& Moore, supra, at 1315 n.225.

80 Prior to the decision in INS v. Chadha, 462 U.S. 919 (1983), Presidents could claim statutory authority for the creation (subject to congressional disapproval) of some offices pursuant to executive reorganization plans. See Reorganization Act of 1977, Pub. L. No. 95-17, 91 Stat. 29. The current version of the Reorganization Act continues to provide that presidential reorganization plans "may provide for the appointment and pay of the head and one or more officers of any agency," 5 U.S.C. § 904(2) (2012), but any such plans now must be affirmatively approved by resolutions of both houses of Congress subject to presidential presentment, see id. $\$ 906$, meaning that offices created by those plans are "established by law." In any event, all such offices, both before and after Chadha, required presidential appointment and senatorial confirmation "if the appointment is not to a position in the competitive service." Id. $\$ 904$. We do not address here whether, as an original matter, Congress could allow Presidents to create offices without specific authorization through Article I, Section 7 legislation. The Office of Legal Counsel has suggested that Presidents might retain some kind of "emergency" power to create offices. See Limitations on Presidential Power, supra note 78, at 78 n.1 ("There may be cases, however-in a national emergency, for example-in which we would conclude that the President may, in effect, create an office in order to carry out constitutional responsibilities that otherwise could not be fulfilled."). We are doubtful of this claim, but we do not pursue that possibility here. There have also been suggestions from time to time that ambassadors can be created without statutory authorization. See West, supra note 70, at 197 . We are doubtful of this claim as well, though if particular "ambassadors" do not actually have legal authority to create rights and obligations, they may not be officers at all. We do not pursue this point either. Clearly, neither a hypothetical "emergency" exception nor an "ambassadorial" exception applies to special counsels.

81 See An Act to Establish the Department of Justice, ch. 150, § 1, 16 Stat. 162, 162 (1870) (codified as amended at 28 U.S.C. $\$ 501$ (2012)). For a detailed history of the development of the Department of Justice, see In re Grand Jury Investigation, 315 F. Supp. 3d 602, 612-17 (D.D.C. 2018), aff'd, 916 F.3d 1047 (D.C. Cir. 2019).

82 See 28 U.S.C. $\$ 503$. 
tually all functions of the Department of Justice, ${ }^{83}$ a Deputy Attorney General $^{84}$ an Associate Attorney General, ${ }^{85}$ a Solicitor General, ${ }^{86}$ eleven Assistant Attorneys General, ${ }^{87}$ one U.S. Attorney for each judicial district ${ }^{88}$ (of which there are currently ninety-four), ${ }^{89}$ a director of the Federal Bureau of Investigation, ${ }^{90}$ a director of the U.S. Marshals Service, ${ }^{91}$ one U.S. Marshal for each judicial district, ${ }^{92}$ a director of the Bureau of Alcohol, Tobacco, Firearms, and Explosives, ${ }^{93}$ a director of the Bureau of Prisons, ${ }^{94}$ twenty-one U.S. Trustees, ${ }^{95}$ and as many assistant United States Attorneys and "Special attorneys" 96 as the Attorney General deems necessary. ${ }^{97}$ We will hear more about "Special attorneys" shortly.

Obviously, this list does not include all of the more than 100,000 persons who work in the Department of Justice. ${ }^{98}$ The vast majority of federal workers, including those who work at the Department of Justice, are not "officers of the United States." They are employees, whose appointments are not controlled by the Appointments Clause and who therefore do not require specific statutory authorization. For their appointments, it suffices to provide, as

83 See id. \$ 509. Those functions, to the extent that they are subject to delegation, are freely delegable. See id. $\$ 510$ ("The Attorney General may from time to time make such provisions as he considers appropriate authorizing the performance by any other officer, employee, or agency of the Department of Justice of any function of the Attorney General.”).

84 See id. $\$ 504$. In the case of vacancy or disability of the Attorney General, the Deputy Attorney General assumes the functions of the Attorney General. See id. $\S 508$.

85 See id. $\$ 504 \mathrm{a}$.

86 See id. $\$ 505$.

87 See id. $\$ 506$. There is also an Assistant Attorney General for Administration. See id. $\S 507$.

88 See id. $\$ 541(\mathrm{a})$.

89 See id. $\$ \$ 81-131$ (establishing ninety-one judicial districts among the fifty states, the District of Columbia, and Puerto Rico); 48 U.S.C. $§ 1424$ (establishing the District Court of Guam); id. $\$ 1611$ (establishing the District Court of the Virgin Islands); id. $\$ 1821$ (establishing the District Court for the Northern Mariana Islands).

90 See Omnibus Crime Control and Safe Streets Act of 1968, Pub. L. No. 90-351, $\S 1101,82$ Stat. 197, 236.

91 See 28 U.S.C. $\$ 561(\mathrm{a})$.

92 See id. at $\$ 561(\mathrm{c})$.

93 See id. at $\S 599 \mathrm{~A}(\mathrm{a})(2)$.

94 See 18 U.S.C. $\$ 4041$ (2012).

95 See 28 U.S.C. $\$ 581$ (2012).

$96 \quad I d . \$ 543$.

97 See id. § 542(a) ("The Attorney General may appoint one or more assistant United States attorneys in any district when the public interest so requires."); $i d$. $\$ 543$ (a) ("The Attorney General may appoint attorneys to assist United States attorneys when the public interest so requires, including the appointment of qualified tribal prosecutors and other qualified attorneys to assist in prosecuting Federal offenses committed in Indian country.").

98 See Department of Justice, FEDERALPAY, https://www.federalpay.org/departments/ departmentofjustice (last visited Sept. 26, 2019) (indicating, on January 20, 2019, that the Department of Justice has 115,583 employees). 
Congress has done, that "[e]ach Executive agency, military department, and the government of the District of Columbia may employ such number of employees of the various classes recognized by chapter 51 of this title as Congress may appropriate for from year to year." 99 If the Department of Justice is given a general appropriation, it can use that money to buy office supplies, vehicles, computer equipment, or personnel, and if the appropriation is truly general, the Department will have discretion about how many and what kind of personnel to hire. But it cannot use a general appropriation to create new constitutional offices and to hire new constitutional officers. Officer positions must be specifically "established by law."

In 1978, the Ethics in Government Act added to the mix an "independent counsel" appointed by a special three-judge court ${ }^{100}$ upon referral by the Attorney General. ${ }^{101}$ The statutory provisions for the independent counsel $^{102}$ expired of their own force in 1999 when Congress failed to reauthorize them. ${ }^{103}$

Shortly before the independent counsel law expired, then-Attorney General Janet Reno promulgated regulations-effective July 1, 1999, and which, if valid, are still in force today-providing for an "Office of Special Counsel."104 Under these regulations (the "Reno Regulations"), the Attorney General may appoint a special counsel if proceedings in a matter by the Department of Justice "would present a conflict of interest for the Department or other extraordinary circumstances; and ... under the circumstances, it would be in the public interest to appoint an outside Special Counsel to assume responsibility for the matter." ${ }^{105}$ The regulations clarify that by "outside" counsel is meant someone "from outside the United States Government," 106 who

shall be a lawyer with a reputation for integrity and impartial decisionmaking, and with appropriate experience to ensure both that the investigation will be conducted ably, expeditiously and thoroughly, and that investigative and prosecutorial decisions will be supported by an informed understanding of the criminal law and Department of Justice policies. ${ }^{107}$

Thus, the Reno Regulations contemplate appointment of a special counsel not currently employed by the government but, in all likelihood, having

995 U.S.C. $\$ 3101$ (2012). Chapter 51 of Title 5 sets out the "General Schedule" of classifications and pay grades for federal employees. See id. \$§ 5101-15.

100 See 28 U.S.C. $\$ \S 49,593$.

101 See id. $\$ 592$.

102 See id. $\$ \$ 591-99$.

103 See id. $\$ 599$ ("This chapter shall cease to be effective five years after the date of the enactment of the Independent Counsel Reauthorization Act of 1994, except that this chapter shall continue in effect with respect to then pending matters before an independent counsel that in the judgment of such counsel require such continuation until that independent counsel determines such matters have been completed.").

104 Reno Regulations, supra note 57.

10528 C.F.R. $\$ 600.1$ (2019) (emphasis added).

$106 I d . \S 600.3(\mathrm{a})$.

$107 I d$. 
prior government experience, most likely in the Department of Justice in some capacity, though no such prior governmental experience is legally necessary for an appointment as special counsel. The Attorney General determines the special counsel's jurisdiction under the Reno Regulations. ${ }^{108}$ Once appointed, "the Special Counsel shall exercise, within the scope of his or her jurisdiction, the full power and independent authority to exercise all investigative and prosecutorial functions of any United States Attorney." 109 There are provisions in the Reno Regulations for providing staff to the special counsel, ${ }^{110}$ for providing for review and oversight by the Attorney General while still ensuring that the "Special Counsel shall not be subject to the day-to-day supervision of any official of the Department [of Justice]," 111 for removal of the special counsel by the Attorney General under carefully defined conditions, ${ }^{112}$ and for reports by the special counsel to the Attorney General $^{113}$ and by the Attorney General to Congress. ${ }^{114}$

In sum, the Reno Regulations, as did the independent counsel statute that preceded them, contemplate appointment, as a putative inferior officer, of a nongovernmental official to an office that is fully the equivalent of a United States Attorney.

United States Attorneys, of course, are created and authorized by statute. The independent counsel from 1978 to 1999 was created and authorized by statute. All other officers in the Department of Justice are created and authorized by statute. No statute, however, creates or authorizes the special counsel. It is purely a creature of the 1999 Janet Reno Regulations. But regulations are not the kind of "law" that can "establish[]" a federal officer. Only a statute can do that under the Appointments Clause, and no statute creates a special counsel with the jurisdiction and authority of Robert Mueller. Even if one believes that Congress can delegate its power to establish by law offices to executive officials, ${ }^{115}$ no existing statute provides that authority to create offices such as the special counsel position held by Mueller. This

\footnotetext{
108 See id. $\$ 600.4$.

109 Id. $\S 600.6$.

110 See id. $\$ 600.5$.

111 Id. $\$ 600.7$.

112 See id. $\$ 600.7(\mathrm{~d})$.

113 See id. $\$ 600.8(\mathrm{a})(2)$.

114 See id. $\$ 600.9$.

115 The question whether Congress could to any extent delegate that power arose early in the nation's history. The first statute for the post office authorized the postmaster to appoint "deputy postmasters, at all places where such shall be found necessary." Act of Feb. 20, 1792, ch. 7, §3, 1 Stat. 232, 234. There were objections on non-subdelegation grounds to this provision, but it was defended by Representative Sedgwick, who noted the precedent of letting the executive determine how many revenue officers to hire. See 3 Annals of Cong. 238-39 (1791). The practice continues today; Congress has specified by statute the precise number of Assistant Attorneys General and U.S. Attorneys but not the precise number of assistant U.S. Attorneys. See 28 U.S.C. $\$ 542$ (2012). It is, of course, debatable whether assistant U.S. Attorneys, or deputy postmasters, are constitutional "Officers of the United States." We discuss the matter briefly infra Section III.A.
} 
conclusion is actually obvious upon careful examination of the relevant statutes; and it ought to be a source of embarrassment to the legal community, and particularly to the Department of Justice, that this lack of statutory authority was not recognized sooner.

The 1999 Reno Regulations purportedly creating the office of special counsel cite as its authority "5 U.S.C. 301; 28 U.S.C. 509, 510, 515-519." 116 In his order appointing Robert Mueller, acting Attorney General Rod Rosenstein cited "28 U.S.C. $\$ \S 509,510$, and 515" as the basis of his statutory authority to appoint a special counsel. ${ }^{117}$ These statutes, singly or collectively, plainly provide no such authority, and it is astonishing that official Department of Justice pronouncements persistently invoke them in this fashion and that lower federal courts sometimes concur.

Start with 5 U.S.C. $\$ 301$. This provision is a general authorization for the issuance of regulations by the Attorney General or any other department head:

The head of an Executive department or military department may prescribe regulations for the government of his department, the conduct of its employees, the distribution and performance of its business, and the custody, use, and preservation of its records, papers, and property. This section does not authorize withholding information from the public or limiting the availability of records to the public. ${ }^{118}$

This is a general housekeeping provision. Rather obviously, nothing in this provision creates any offices or authorizes the creation (or abolition!) of any offices. As one district court aptly put it, "[t] his power to 'keep house,' however, is not the same as the power to 'build the house' by appointing officers." 119 Indeed, if $\S 301$ was taken as general authorization for appointment (or abolition!) of officers, the entirety of the more numerous specific provisions for appointment of officers throughout the United States Code would be superfluous. ${ }^{120}$ That is an absurd construction of $\S 301$, and we do not understand anyone seriously to advance it. ${ }^{121}$

\footnotetext{
116 Reno Regulations, supra note 57, at 37,042.

117 See Appointment Memo, supra note 2.

118 5 U.S.C. $\$ 301$ (2012).

119 United States v. Concord Mgmt. \& Consulting LLC, 317 F. Supp. 3d 598, 622 (D.D.C. 2018).

120 See id.

121 But see Willy v. Admin. Review Bd., 423 F.3d 483, 491-92 (5th Cir. 2005) (relying on both $\S 301$ and a 1950 reorganization act in finding that the Secretary of Labor could create and appoint inferior officers to an administrative review board with final decisional authority); United States v. Janssen, 73 M.J. 221, 224-25 (C.A.A.F. 2014) (noting, and roundly rejecting, a claim by the government that section 301 authorizes appointment of a civilian to a military court of appeals);. As did the court in Janssen, see Janssen, 73 M.J. at 224, we think that Willy was obviously wrong to rely, to any extent, on $\$ 301$ as authority to appoint an officer. Whether Willy properly relied on the applicable reorganization act, which was specific to the Department of Labor, see Reorganization Plan No. 6 of 1950, 15 Fed. Reg. 3174, 3174 (March 13, 1950), is a matter for another time.
} 
Section 509 of Title 28 merely says that "[a]ll functions of other officers of the Department of Justice and all functions of agencies and employees of the Department of Justice are vested in the Attorney General," except for some functions not relevant here. ${ }^{122}$ This provision does not authorize the creation of an office of special counsel or the appointment of private persons to that office. Indeed, it does not authorize the appointment of anyone to anything. It simply says that the Attorney General can control all of his or her subordinates in the Justice Department or, if he or she wishes, personally assume and exercise their responsibilities. It does not remotely create any office or say anything about who those subordinates might be. We are at a loss to imagine how the Department of Justice could ever have thought otherwise.

Section 510 of Title 28, for its part, merely says: "The Attorney General may from time to time make such provisions as he considers appropriate authorizing the performance by any other officer, employee, or agency of the Department of Justice of any function of the Attorney General."123 This provision is also quite unremarkable and contains no explicit statutory language creating an office or authorizing the Attorney General to appoint private persons like Robert Mueller to be officers of the United States to whom the Attorney General can delegate prosecutorial authority. As with $\S 509$, the statute provides for moving authority around among the persons who are part of the Department of Justice, but it says nothing about who those persons are or how those persons got there. Other statutes, as we have already seen, define the personnel in the Department of Justice. Sections 509 and 510 operate once those personnel are known, but those sections say nothing about who those personnel shall be. The Attorney General can move his subordinate players around the chess board, but he cannot create a new queen.

One should also note that, while $\$ 510$ seems categorical in its language permitting delegation of the Attorney General's functions, that language is qualified by background constitutional and statutory understandings about the nature of delegable authority. Notwithstanding $\S 510$, not everything within the Attorney General's power can be delegated to anyone. Some functions, for example, can only be performed by officers rather than employees. Surely, for example, the Attorney General cannot authorize a random "employee" of the Department of Justice to control all federal litigation or appoint a special counsel. Section 510 confirms the Attorney General's power to delegate his or her delegable functions, but it leaves to other sources of law the determination of which functions are delegable and to whom.

The only other provision cited by acting Attorney General Rosenstein in his Mueller appointment memo was 28 U.S.C. \$515. Attorney General Reno's regulations relied on 28 U.S.C. $\$ \$ 515-19$. Again, alone or singly,

12228 U.S.C. $\$ 509$ (2012). The excepted functions are those functions "(1) vested by subchapter II of chapter 5 of title 5 in administrative law judges employed by the Department of Justice; (2) of the Federal Prison Industries, Inc.; and (3) of the Board of Directors and officers of the Federal Prison Industries, Inc." Id.

123 Id. $\$ 510$. 
none of these provisions comes close to authorizing creation of a special counsel or the appointment by the Attorney General of a private person to the position.

Section 515(a) confers the following power:

The Attorney General or any other officer of the Department of Justice, or any attorney specially appointed by the Attorney General under law, may, when specifically directed by the Attorney General, conduct any kind of legal proceeding, civil or criminal, including grand jury proceedings and proceedings before committing magistrate judges, which United States Attorneys are authorized by law to conduct, whether or not he is a resident of the district in which the proceeding is brought. ${ }^{124}$

Section 515 (a) does not create any offices or authorize the appointment of any new private citizen special counsels like Robert Mueller. Section 515(a) concerns the powers of people who have been properly appointed to offices "under law" pursuant to other statutory provisions, and allows the Attorney General to designate a U.S. Attorney or a special attorney appointed "under law" to prosecute a case "whether or not he is a resident of the district in which the proceeding is brought." 125 Section 515(a) is thus a geographical and jurisdictional allocative provision and not a grant of power to appoint private citizens to be special counsels. As we have already explained, ${ }^{126}$ in 2007 , this clause allowed the Attorney General ${ }^{127}$ to appoint, for example, Patrick Fitzgerald, who at the time of his appointment as special counsel was already the appointed-under-law U.S. Attorney for the Northern District of Illinois, to take on the germane duty of being a special counsel to investigate the Valerie Plame affair, which arose in the District of Columbia. Section 515(a) also allowed, in 2012, for former Maryland United States Attorney Rod Rosenstein to be appointed by then-Attorney General Eric Holder to investigate leaks in the District of Columbia. More recently, former Attorney General Jeff Session used Section 515(a) to ask Utah United States Attorney John Huber to investigate alleged politicization of the FBI. All of these United States Attorneys were already (superior) officers of the United States, nominated by the President and confirmed by the Senate, in offices "established by Law," who were tasked with bringing legal proceedings outside their own districts. Section 515(a) permits this geographical flexibility-the ability, as we said, of the Attorney General to move his chess pieces on the board, but not the power to create a new queen.

Section 515 goes on to add in subsection (b):

\footnotetext{
$124 I d . \S 515(\mathrm{a})$.

$125 I d$.

126 See supra notes 15-17 and accompanying text.

127 Actually, the appointment came from Deputy Attorney General James B. Comey, after Attorney General John Ashcroft recused himself from the matter. See Dan Eggen \& Mike Allen, Ashcroft Recuses Self from Leak Case, WAsH. Post (Dec. 31, 2003), https:// www.washingtonpost.com/archive/politics/2003/12/31/ashcroft-recuses-self-from-leakcase/53c7218b-24e6-4b03-8759-0e134d4551fb/.
} 
Each Attorney specially retained under authority of the Department of Justice shall be commissioned as special assistant to the Attorney General or special attorney, and shall take the oath required by law. Foreign counsel employed in special cases are not required to take the oath. The Attorney General shall fix the annual salary of a special assistant or special attorney. ${ }^{128}$

One recent district court decision relied heavily, but mistakenly, on this provision in its decision upholding the validity of Mueller's appointment, saying that this provision authorized the hiring of new independent special counsels of the kind contemplated in Attorney General Janet Reno's regulations. ${ }^{129}$ The wording of $\S 515(\mathrm{~b})$, however, refers in the past tense only to attorneys "specially retained under the authority of the Department of Justice" to whom it gives a title, salary, and commission. ${ }^{130}$ This is not a grant of new power to retain or to hire new officers, but it is instead a provision that provides on its face that attorneys, who may very well be only employees and not officers, ${ }^{131}$ and who have already been hired or retained, can also have a title and a salary. Section 515(b) is phrased in the past tense and refers to hires that have already been made. Indeed, the aforementioned district court decision used brackets to remove the tenses from the operative verbs in $\S 515 .{ }^{132}$

To be sure, $\S \S 515(\mathrm{a})$ and 515 (b) both assume that there are going to be attorneys "specially appointed by the Attorney General under law" 133 and "specially retained under the authority of the Department of Justice." 134 And there is in fact an explicit provision elsewhere in Title 28 authorizing the Attorney General to hire such persons, who can then be denominated and commissioned as "special assistant[s]" or "special attorney[s]" under $\S 515$ (b). We will come to that provision shortly. If, as we claim, there is such a provision that actually authorizes the appointment of special counsels, why does the Department of Justice not rely upon it but instead cite obviously inapplicable provisions such as $§ 515$ ? We will solve that mystery in short order, but let us first deal with the rest of the cited but inapposite provisions.

Section 516 provides, in full: "Except as otherwise authorized by law, the conduct of litigation in which the United States, an agency, or officer thereof is a party, or is interested, and securing evidence therefor, is reserved to

\footnotetext{
12828 U.S.C. $\$ 515$ (b).

129 See In re Grand Jury Investigation, 315 F. Supp. 3d 602, 654-58 (D.D.C. 2018), aff'd, 916 F.3d 1047 (D.C. Cir. 2019).

13028 U.S.C. $\$ 515$ (b).

131 The requirement that such attorneys be commissioned suggests that they are officers, as the Constitution requires that all officers be commissioned. See U.S. ConsT. art. II, $\S 3$ (stating that the President "shall Commission all the Officers of the United States"). All officers must be commissioned, but we do not discuss here whether all those commissioned must be officers. We do discuss the important distinction between employees and officers shortly. See infra Section III.A.
}

132 See In re Grand Jury Investigation, 315 F. Supp. 3d at 618.

13328 U.S.C. $\$ 515$ (a).

134 Id. $\$ 515(\mathrm{~b})$. 
officers of the Department of Justice, under the direction of the Attorney General." ${ }^{355}$ No office creating power here! Section 517 provides, in full: "The Solicitor General, or any officer of the Department of Justice, may be sent by the Attorney General to any State or district in the United States to attend to the interests of the United States in a suit pending in a court of the United States, or in a court of a State, or to attend to any other interest of the United States." ${ }^{136}$ No office creating power here either! Section 518 provides, in full:

(a) Except when the Attorney General in a particular case directs otherwise, the Attorney General and the Solicitor General shall conduct and argue suits and appeals in the Supreme Court and suits in the United States Court of Federal Claims or in the United States Court of Appeals for the Federal Circuit and in the Court of International Trade in which the United States is interested.

(b) When the Attorney General considers it in the interests of the United States, he may personally conduct and argue any case in a court of the United States in which the United States is interested, or he may direct the Solicitor General or any officer of the Department of Justice to do so. ${ }^{137}$

Again, no office creating power here. Section 519 provides, in full:

Except as otherwise authorized by law, the Attorney General shall supervise all litigation to which the United States, an agency, or officer thereof is a party, and shall direct all United States Attorneys, assistant United States Attorneys, and special attorneys appointed under section 543 of this title in the discharge of their respective duties. ${ }^{138}$

No office creating power here either. Rather obviously, none of these provisions has anything to do with the creation of or appointment to offices.

The last of these provisions, however, points the way to the correct answer regarding the Attorney General's statutory authority to appoint special counsels. Section 519 notes that there are "special attorneys appointed under section 543 of this title." 139 Indeed there are. Section 543 of Title 28 is explicit authority for the Attorney General to appoint special counsels. Yet neither the 1999 Reno Regulations nor the Rosenstein memo of May 17, 2017, appointing Robert Mueller makes any mention of this provision. Why not?

Because Section 543 does not authorize the kind of special counsel contemplated by the Reno Regulations or the Rosenstein appointment of Mueller. Section 543 is narrowly cabined, as one would expect from the overall structure of Title 28. The government for decades has steadfastly refused to rely on this provision that explicitly provides the Attorney General with hiring authority, and it continues to refuse to rely on it in current litigation concerning special

$\begin{array}{ll}135 & \text { Id. } \$ 516 . \\ 136 & \text { Id. } \$ 517 . \\ 137 & \text { Id. } \$ 518 . \\ 138 & \text { Id. } \$ 519 . \\ 139 & \text { Id. }\end{array}$


counsels-for the obvious reason that the provision contains internal limitations which the government seeks to avoid.

Section 543 of Title 28 provides:

(a) The Attorney General may appoint attorneys to assist United States Attorneys when the public interest so requires, including the appointment of qualified tribal prosecutors and other qualified attorneys to assist in prosecuting Federal offenses committed in Indian country.

(b) Each attorney appointed under this section is subject to removal by the Attorney General.

(c) Indian Country.-In this section, the term "Indian country" has the meaning given that term in section 1151 of title $18 .{ }^{140}$

This is an obvious and explicit authorization for the creation and appointment of special assistants or special counsels to assist U.S. Attorneys when the public interest so requires. There are many contexts in which the appointment of such persons makes sense. The government will often encounter problems for which private lawyers have expertise-either gained from past government service or on their own-on matters such as organized crime, banking, antitrust, tribal law, and so forth. Those lawyers may not want a permanent government position but may be willing to help the government on a limited basis, perhaps as part of a task force or a team dealing with a specific piece of complex litigation requiring expert knowledge. An appointment as a special assistant or special counsel, under the control and direction of a United States Attorney, is an obvious win-win solution in many cases.

The problem for the government in the case of the 1999 Reno Regulations and the Mueller appointment is that the 1999 Reno Regulations and the Mueller appointment order of May 17, 2017, do not contemplate special counsels who assist U.S. Attorneys; they contemplate special counsels who replace U.S. Attorneys in specific cases. Robert Mueller, for example, was not appointed to assist U.S. Attorneys or to prosecute in Indian country. He was hired as a stand-alone officer who replaces rather than assists the functions of United States Attorneys within the scope of his jurisdiction. This is precisely the role that the Ethics in Government Act explicitly authorized for independent counsels. But that statute no longer exists, and in the absence of that statute or a similar provision, there is simply no statutory office of special counsel to which Mueller could be appointed to function as a stand-in for a U.S. Attorney.

Section 543 thus provides the hiring authority that is cross-referenced but not created by $\S \S 515$ and 519 . Once again, these latter provisions allow the Attorney General of the United States to move his or her pieces in the law enforcement chess game all over the board, but they do not give him or her the power to create a new queen. It takes a law to do that. Section 543 is such a law. It explicitly permits special counsels. It just does not permit the kind of special counsel that is Robert Mueller or that is generally contemplated by the Reno Regulations.

$140 \quad I d . \S 543$. 
The remainder of Title 28 confirms this obvious conclusion. Section 533, entitled "Investigative and Other Officials," says:

The Attorney General may appoint officials-

(1) to detect and prosecute crimes against the United States;

(2) to assist in the protection of the person of the President; and

(3) to assist in the protection of the person of the Attorney General;

(4) to conduct such other investigations regarding official matters under the control of the Department of Justice and the Department of State as may be directed by the Attorney General. ${ }^{141}$

This is also an explicit authorization for appointment of persons within the Department of Justice, but again the authorization is strictly limited and has no bearing on the appointment of special counsels such as Robert Mueller. Contrary to the views of a recent district court opinion ${ }^{142}$ and the court of appeals decision that affirmed it, ${ }^{143}$ Section 533(1) is not a general authorization to the Attorney General to appoint anyone and everyone. It specifically and solely authorizes the appointment of "Investigative and Other Officials" 144 -officials, not officers-connected with the FBI. This does not include special counsels. We know this for three reasons.

First, $\S 533$ is part of Chapter 33 of Title 28, encompassing $\S \S 531-540 \mathrm{C}$, which deals with the "Federal Bureau of Investigation." Section 532, which immediately precedes $\S 533$, is entitled "Director of the Federal Bureau of Investigation," and it spells out the Attorney General's authority over the FBI. Section 534, which follows $\S 533$, is about preserving evidence in criminal cases. Section 533 clearly deals with FBI officials and agents, not special counsels. This is how the government has long understood this provision, which has been employed as the basis for the FBI's law enforcement authority. Not surprisingly, Rod Rosenstein in his order appointing Robert Mueller to be special counsel did not cite $\S 533$ as a source of authority, ${ }^{145}$ nor do the 1999 Reno Regulations refer to it. ${ }^{146}$

Second, $\$ 533$ concerns the appointment of investigative and prosecutorial "officials." Such officials, as that term is used in the statute, ${ }^{147}$ are not constitutional officers of the United States and cannot perform the functions of officers of the United States. They are nonofficer employees,

$141 \quad I d . \S 533$ (footnotes omitted).

142 See In re Grand Jury Investigation, 315 F. Supp. 3d 602,652-54 (D.D.C. 2018), aff'd, 916 F.3d 1047 (D.C. Cir. 2018).

143 In re Grand Jury Investigation, 916 F.3d 1047, 1056 (D.C. Cir. 2018).

14428 U.S.C. $\$ 533$ (emphasis added).

145 See Appointment Memo, supra note 2.

146 See Reno Regulations, supra note 57.

147 An eighteenth-century statute might well have used a term such as "officials" to have a broader meaning than we attribute to the term in $\$ 533$. See Lucia v. SEC, 138 S. Ct. 2044, 2056-57 (2018) (Thomas, J., concurring). As a matter of statutory interpretation, however, there is no plausible case for reading the term as it appears in $\S 533$ to be coextensive with the constitutional meaning of "officer," for the reasons that we give below. 
who, as FBI agents, must be subject to the supervision and direction of officers of the United States.

As we previously noted, most of the people who work for the United States government, including those in the FBI and other parts of the Department of Justice, are employees rather than officers. The distinction matters because officers of the United States must be established by law and appointed in conformance with the terms of the Appointments Clause. Employees and FBI agents, by contrast, can be appointed by any means that Congress deems "necessary and proper" for carrying out governmental functions, and the hiring (purchase) of employees does not require any authority more specific than the authority required to hire (purchase) staplers, thumb drives, or trash cans. ${ }^{148}$ One can see the nature of $\S 533$ 's authorization by looking at subsections (2)-(4). Those subsections describe persons who perform important, and even vital, functions in the government, but they are not the kinds of decision-making and policy-making functions that mark out someone as a constitutional officer. In that same company we find FBI personnel who can "detect and prosecute crimes against the United States."149 Many people can and must participate in the investigative and prosecutorial process without being officers of the United States. The FBI needs office and field personnel to perform its functions, and $\S 533$ allows the agency to have them. But those office and field personnel are not officers of the United States and do not have the range and power of a special counsel.

Further considerations show that the "officials" mentioned in $\S 553$ are not officers, such as special counsels. The word "Officer" is a constitutional term of art, not only because it is used that way in the Appointments Clause, but also because Article II, Section 4 allows for the impeachment and removal from office of "all civil Officers of the United States." 150 Congress can try to impeach the Deputy Attorney General or the FBI Director, but no one thinks Congress can impeach Department of Justice trial attorneys, Office of Legal Counsel attorney-advisers, or lower-level officials or field personnel at the FBI. Officials are employees. Officers of the United States have a duty-an officium in Latin. Officers can be put by Congress in the line of succession to the presidency. ${ }^{151}$ No one thinks that investigative officials at the FBI or Department of Justice trial attorneys, who are bureaucrats and employees, can be put in the line of succession to the presidency. That simply is not how Congress was using the term "officials" in $§ 533$.

Third, and perhaps most tellingly, a cavalier reading of $\S 533$ to authorize hiring beyond its obvious scope obliterates the careful structure of Title

148 The district judge in In re Grand Jury Investigation did not understand this basic point. See In re Grand Jury Investigation, 315 F. Supp. 3d at 651 n.34.

14928 U.S.C. $\$ 533(1)(2012)$.

150 U.S. Const. art. II, $\$ 4$.

151 See id. art. II, $\S 1$, cl. 6 ("[T] he Congress may by Law provide for the Case of Removal, Death, Resignation or Inability, both of the President and Vice President, declaring what Officer shall then act as President, and such Officer shall act accordingly, until the Disability be removed, or a President shall be elected."). 
28. Title 28 is divided into chapters dealing with the Attorney General; ${ }^{152}$ the FBI; ${ }^{153}$ U.S. Attorneys; ${ }^{154}$ the Marshals Service; ${ }^{155}$ U.S. Trustees; ${ }^{156}$ the Bureau of Alcohol, Tobacco, Firearms and Explosives ( $§ 599 \mathrm{~A}-599 \mathrm{~B}) ;{ }^{157}$ and the now-sunsetted independent counsel. ${ }^{158}$ It is pellucidly clear that wide-ranging special counsels of the sort represented by Robert Mueller are not part of these provisions outside of the now-defunct Ethics in Government Act sections. At a more granular level, the effect of a loose reading of the statutes is even more bizarre. Congress, as we earlier saw, has provided for the appointment, all with presidential nomination and senatorial consent, of a Deputy Attorney General, ${ }^{159}$ an Associate Attorney General, ${ }^{160}$ a Solicitor General, ${ }^{161}$ exactly eleven Assistant Attorneys General (plus an Assistant Attorney General for Administration who is in the competitive service and is appointed by the Attorney General), ${ }^{162}$ and exactly one U.S. Attorney for each judicial district, ${ }^{163}$ of which there are currently ninety-four. A reading of $\S 533$ to create essentially unlimited inferior officer appointment power in the Attorney General wreaks havoc on this structure.

Robert Mueller performed the functions of, at a minimum, a U.S. Attorney, as the Reno Regulations specifically contemplate. If the Attorney General can use $\$ 533$ to appoint special counsels to replace, and not simply to "assist," U.S. Attorneys, he can presumably use the same provision to appoint people to replace, and not simply assist, Assistant Attorneys General, the Solicitor General, and the Deputy Attorney General as well. Congress has crafted a structure for the Department of Justice that assures that law enforcement power is channeled through senatorially confirmed officers of defined numbers (eleven Assistant Attorneys General and, as of the writing of this Article, ninety-three United States Attorneys). It makes no sense at all to read these statutes as additionally authorizing the Attorney General alone to then hire whomever he or she pleases to displace the functions of the statutorily specified officers with persons who were not subject to senatorial confirmation. That is obviously not what $\S 533$ is about.

To be clear: the Attorney General has ample authority to hire employees and lawyers, just as he or she has ample authority to hire other support staff and purchase office supplies. But those lawyers must fit within the statutory structure prescribed by Congress, which means that any lawyers who are

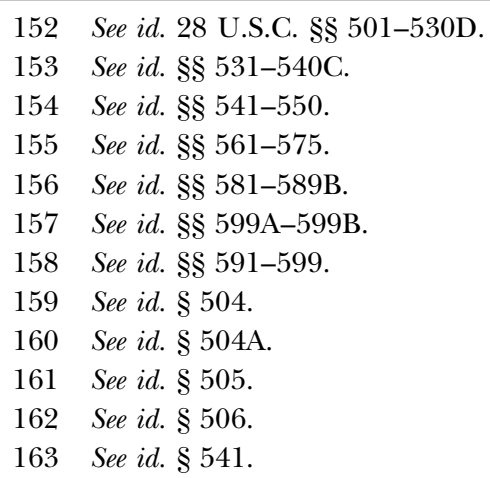


officers ${ }^{164}$ must "assist" rather than replace the United States Attorneys, Assistant Attorneys General, and other presidentially appointed and senatorially confirmed officers who Congress has specifically created. Robert Mueller was not part of a task force run by U.S. Attorneys. He was not assisting a U.S. Attorney by providing special expertise in, for example, organized crime or antitrust law. He functioned as a freestanding officer within the Department of Justice. There is no statutory authorization for such a position.

\section{B. No Statute Authorizes the Appointment of a Special Counsel with Robert Mueller's Range of Authority Without Presidential Nomination and}

Senatorial Consent

There is an additional reason why the authorities relied upon for decades by the government as authorization for special counsels fail to provide the necessary legal authorization for the creation of those positions. A special counsel under the 1999 Reno Regulations exercises all of the powers of a U.S. Attorney. We will demonstrate below that this makes such special counsels superior officers who must, as a constitutional matter, be appointed by the President and confirmed by the Senate. But even if such special counsels are not superior officers, they are, at a minimum, inferior officers. Under the terms of the Appointments Clause, all federal officers, both superior and inferior, must be appointed by the President with the advice and consent of the Senate unless (1) the officer in question is an inferior officer, and (2) Congress has "by Law" specified that the officer can be appointed by the President alone, the courts of law, or the head of a department. ${ }^{165}$ The Appointments Clause itself thus specifies a rule of construction requiring a clear congressional statement that any inferior federal officer's appointment be without presidential appointment and senatorial confirmation in order for that to happen. ${ }^{166}$ Absent this clear specification, any officer of the United States, however created, must be appointed by the President with the advice and consent of the Senate.

Sound principles of constitutional structure yield this clear statement rule, as they yield other clear statement rules. ${ }^{167}$ While one normally thinks of the Appointments Clause as a "separation of powers" rather than a "federalism" provision, it contains important elements of each. The default rule for officer appointments does not require confirmation by Congress as a whole. It requires confirmation by the Senate. The Senate is the preserve of the

164 If a lawyer is not an officer, the hiring of that person stands on no different footing than does the hiring of a filing clerk or janitorial staff. There is both a statutory and a constitutional difference between the hiring of employees and the hiring of officers. But, of course, if the lawyer is not an officer, that person cannot possibly exercise the range of authority exercised by a special counsel. See infra Section III.A.

165 See U.S. Const. art. II, § 2, cl. 2.

166 See United States v. Maurice, 26 F. Cas. 1211, 1214 (C.C.D. Va. 1823) (No. 15,747).

167 See, e.g., Gregory v. Ashcroft, 501 U.S. 452, 460-61, 469-70 (1991) (describing a clear statement rule for construing federal statutes that interfere with state governmental authority). 
smaller states, who are each guaranteed representation in equal number to the larger states. The Senate's confirmation role thus assures the smaller states a say in the vital questions of executive staffing. If left only to presidential discretion, large-state Presidents (and the Electoral College favors largestate Presidents) might underrepresent the smaller states in the executive departments-a possibility of which the framing generation was acutely aware. As one Convention participant put it, unchecked presidential appointment "would put it in his power to gain over the larger States, by gratifying them with a preference of their Citizens."168 These constitutional concerns warrant an interpretative presumption in favor of a clear statement of congressional intent to authorize appointment of an inferior officer by any means other than presidential nomination and senatorial consent. The constitutional structure and the prerogatives of the Senate both demand it.

Congress knows how to overcome that presumption. When Congress chooses to "by Law vest the Appointment of such inferior Officers, as they think proper, in the President alone, in the Courts of Law, or in the Heads of Departments," it uses explicit statutory language in doing so, as we made clear in the Introduction to this article. ${ }^{169}$

Consider also in this regard 28 U.S.C. $\$ 546(\mathrm{~d})$, which governs the power to appoint interim U.S. Attorneys as inferior officers ${ }^{170}$ : "If an appointment expires under subsection (c) (2), the district court for such district may appoint a United States Attorney to serve until the vacancy is filled. The order of appointment by the court shall be filed with the clerk of the court." 171 This is clear statutory language that a federal district judge, one of the constitutional "Courts of Law," "may appoint" inferior officers.

Similarly, 28 U.S.C. $§ 593$ (b) — part of the Ethics in Government Act of 1978, which sunsetted out of existence in 1999-provided that a special three-judge court appointed by the Chief Justice of the United States, when the Attorney General referred a case to it, could appoint inferior officers. The statute said that upon receiving an application from the Attorney General, the court, which the Act called a special division, "shall appoint an appropriate independent counsel and shall define that independent counsel's prosecutorial jurisdiction."172 Once again, we see clear statutory language saying that the three-federal-judge special division "shall appoint" an

1682 Records of the Federal Convention, supra note 72, at 43 (statement of Mr. Bedford).

169 See U.S. Const. art. II, § 2, cl. 2.

170 The statute, of course, assumes that interim U.S. Attorneys are inferior rather than superior officers. As a matter of constitutional law, we doubt this conclusion. See infra subsection III.B.2. But for purposes of illustrating Congress's use of express language authorizing appointment by means other than presidential nomination and senatorial consent, it does not matter whether Congress's constitutional judgment about the status of interim U.S. Attorneys was correct.

17128 U.S.C. $\$ 546$ (d) (2012).

172 Id. $\S 593$ (b) (1). 
independent counsel, who was deemed an inferior officer by the Supreme Court in Morrison v. Olson. ${ }^{173}$

And, as we mentioned in the Introduction, the organic statutes of the Departments of Agriculture, Education, Health and Human Services, and Transportation all contain clear officer-appointment-granting clauses. Thus, the Agriculture Secretary "may appoint such officers and employees . . . and such experts, as are necessary to execute the functions vested in him." 174 The Education Secretary "is authorized to appoint and fix the compensation of such officers and employees, including attorneys, as may be necessary to carry out the functions of the Secretary and the Department." ${ }^{775}$ The Health and Human Services Secretary "is authorized to appoint and fix the compensation of such officers and employees." 176 The Transportation Secretary "may appoint and fix the pay of officers and employees of the Department of Transportation." 177 The Administrative Procedure Act, for its part, says "[e]ach agency shall appoint as many administrative law judges as are necessary for [hearing and deciding cases.]"178

There is no such clear language in the existing statutes for the Department of Justice relied upon by the government in the Reno Regulations and Mueller appointment memo. The only relevant language is in $\$ \S 515,533$, and 543 , and we have already seen that the former two provisions simply do not create any hiring authority while the latter does not authorize the kind of special counsel created by the Reno Regulations. None of these provisions specifically gives the Attorney General power to appoint officers. That is especially significant because there is in fact one provision pertaining to the Department of Justice that does specifically give the Attorney General a broad-based power to appoint officers. The statutory provision for the Director of the Bureau of Prisons reads: "The Bureau of Prisons shall be in charge of a director appointed by and serving directly under the Attorney General. The Attorney General may appoint such additional officers and employees as he deems necessary." 179 Thus, the Attorney General has specific, explicit authority to hire officers for the Bureau of Prisons-but not elsewhere.

The Appointments Clause creates a default rule that all officers of the United States, whether inferior or superior, must be nominated by the President and confirmed by the Senate. It takes affirmative action through passage of a statute for Congress to vest in the Attorney General the power to appoint an inferior officer to be a special counsel. Since Congress has never passed such a statute, Robert Mueller could not have been appointed by any means other than presidential nomination and senatorial consent even if he was an inferior rather than a superior officer.

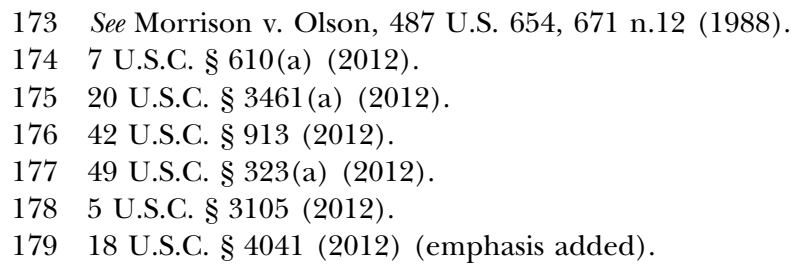


Because the statutes invoked by the Department of Justice do not actually authorize the creation and appointment of special counsels, they naturally contain no limits on such a (fictitious) power. The power that the Department of Justice claims in the 1999 Reno Regulations is not cabined by law because it is not rooted in law. It could lead to an Attorney General appointing inferior officer special counsels in states with senators of the opposite political party from the White House. It could lead to appointment of an inferior officer shadow of the Solicitor General or of the Assistant Attorney General of the Criminal Division. Through its regulations and its appointment of Mueller, the Department of Justice is claiming that it has absolute power to appoint inferior officer special counsels-and, as Lord Acton said, "absolute power corrupts absolutely."180 There is no chance at all that either the careful structure of Title 28 or the Constitution permits this extravagance.

All of this suggests the wisdom of reading the statutes that Congress has enacted to mean exactly what they say. There is no freewheeling power in the Attorney General to appoint private persons like Robert Mueller to inferior officer status. Acting Attorney General Rosenstein should have, instead of appointing Robert Mueller to investigate the alleged collusion-with-Russia scandal, appointed one of the Senate-confirmed United States Attorneys to take on that job in addition to pursuing their other duties. Robert Mueller could then "assist" that United States Attorney if such was deemed necessary. That is the road not taken, but it is the only road that the law permits.

\section{Our Reading of the Statutes Is Consistent with the Watergate Tapes Case}

At least one district judge agrees wholly with our statutory analysis, concluding that the various provisions cited by the government, alone or in combination, "do not explicitly authorize' the Acting Attorney General to appoint a Special Counsel." 181 The court specifically rejects the idea that either $\$ 515$ (b) or $\$ 533$ can provide the necessary authorization, essentially for the reasons that we have provided here. ${ }^{182}$ The court nonetheless upheld the appointment of Robert Mueller as special counsel on the ground that binding precedent, however faultily reasoned, already settled the matter. In particular, the court believed that the Supreme Court's decision in United States v. Nixon, ${ }^{183}$ the Watergate Tapes case, which granted Special Counsel Leon Jaworski's request for a subpoena of Richard Nixon's tapes, implicitly assumed that Leon Jaworski was legally appointed even though that issue was

180 Letter from Lord Acton to Archbishop Mandell Creighton (Apr. 5, 1887), reprinted in 1 Lectures on Modern History (John Neville Figgis \& Reginald Vere Laurence eds., 1906), http://oll.libertyfund.org/titles/acton-acton-creighton-correspondence\#lf1524_ label_010.

181 United States v. Concord Mgmt. \& Consulting LLC, 317 F. Supp. 3d 598, 618 (D.D.C. 2018) (quoting In re Sealed Case, 829 F.2d 50, 55 (D.C. Cir. 1987)).

182 See id. at $618-20$ (rejecting $\$ 533$ as a source of authority to hire special counsels); $i d$. at 620-21 (rejecting $\$ 515(\mathrm{~b})$ as a source of authority to hire special counsels).

183418 U.S. 683 (1974). 
never raised, briefed, argued, or decided in United States $v$. Nixon. Similar reliance was placed on the D.C. Circuit's decision in In re Sealed Case, ${ }^{184}$ which concerned the appointment of an Iran-Contra special counsel. The District Court thus held:

Even though the statutes "do not explicitly authorize" the Acting Attorney General to appoint the Special Counsel, Nixon and Sealed Case establish that the statutory provisions "accommodat[e] the delegation at issue." In re Sealed Case, 829 F.2d at 55. Both cases involved similar officers: special prosecutors appointed via Department of Justice regulations. In both, the Supreme Court and the D.C. Circuit stated that Congress empowered the Attorney General to appoint the officers, albeit without analyzing specifically how any individual provision or combination of provisions accomplished this. ${ }^{185}$

Another district court, whose independent statutory reasoning was not nearly as careful as that of the judge in Concord Management, also relied heavily on United States $v$. Nixon as recognizing statutory authority to appoint a special counsel with broad powers. ${ }^{186}$ In affirming that decision, the D.C. Circuit went even further: "Because binding precedent establishes that Congress has 'by law' vested authority in the Attorney General to appoint the special counsel as an inferior officer, this court has no need to go further to identify the specific sources of this authority." 187 And indeed the court made no effort to identify any such sources of authority. ${ }^{188}$ All of these courts are mistaken. Even if one believes that court decisions establish law superior to statutes, neither Nixon nor In re Sealed Case can carry the weight of sustaining the 1999 Reno Regulations or the creation of Robert Mueller's office and his appointment to it.

Here is the entire discussion (sans unhelpful footnotes) of the relevant statutes from the opinion in United States $v$. Nixon:

Our starting point is the nature of the proceeding for which the evidence is sought-here a pending criminal prosecution. It is a judicial proceeding in a federal court alleging violation of federal laws and is brought in the name of the United States as sovereign. Berger v. United States, 295 U.S. 78,88 (1935). Under the authority of Art. II, $\$ 2$, Congress has vested in the Attorney General the power to conduct the criminal litigation of the United States Government. 28 U.S.C. $\$ 516$. It has also vested in him the power to

\footnotetext{
184829 F.2d 50.

185 Concord Mgmt. E Consulting, 317 F. Supp. 3d at 622 (citation omitted).

186 See In re Grand Jury Investigation, 315 F. Supp. 3d 602, 652 (D.D.C. 2018), aff'd, 916 F.3d 1047 (D.C. Cir. 2019).

187 In re Grand Jury Investigation, 916 F.3d at 1054 (emphasis added).

188 The D.C. Circuit did not address whether the Constitution requires a "clear statement" rule for appointment of special counsels without presidential nomination and senatorial confirmation, because "Miller's cursory references to a 'clear statement' argument he presented to the district court are insufficient to preserve that issue for appeal and it is forfeited." Id. In light of the arguments actually presented in that case, we find this conclusion somewhere between puzzling and inexplicable, but the point is incidental to our analysis.
} 
appoint subordinate officers to assist him in the discharge of his duties. 28 U.S.C. $\S \S 509,510,515,533$. Acting pursuant to those statutes, the Attorney General has delegated the authority to represent the United States in these particular matters to a Special Prosecutor with unique authority and tenure. The regulation gives the Special Prosecutor explicit power to contest the invocation of executive privilege in the process of seeking evidence deemed relevant to the performance of these specially delegated duties. 38 Fed. Reg. 30739, as amended by 38 Fed. Reg. $32805 .^{189}$

For three reasons, this discussion does not remotely settle the legality of the Reno Regulations or Robert Mueller's appointment.

First, and most importantly, the discussion is pure dictum. As one district judge recently recognized, "no party in Nixon had disputed that Congress had authorized the Attorney General to appoint the Watergate Special Prosecutor."190 This judge and the judge in Concord Management, however, both maintained that this discussion was nonetheless "necessary to the Court's conclusion that a justiciable controversy existed," 191 and was a "necessary step[ ]"192 in the Court's reasoning. The D.C. Circuit said much the same thing:

The Supreme Court held there was a justiciable controversy because the regulations issued by the Attorney General gave the Special Prosecutor authority to contest the President's invocation of executive privilege during the investigation. In this analysis, the Attorney General's statutory authority to issue the regulations was a necessary antecedent to determining whether the regulations were valid, and, therefore, was necessary to the decision that a justiciable controversy existed. ${ }^{193}$

That is simply wrong. It fundamentally misunderstands what was at issue in United States v. Nixon.

The issue in Nixon was whether the President's assertion of executive privilege could be challenged in court by an official-really any official-in the Department of Justice. President Nixon maintained that because the President ultimately controls both law enforcement and the assertion of executive privilege, and the President had not delegated to anyone responsibility to determine the propriety of claims of executive privilege, disagreements between the President and subordinate law enforcement officials about what matters were covered by executive privilege did not present a justiciable controversy but were simply intradepartmental disputes beyond the cognizance of the courts. ${ }^{194}$ This is purely a constitutional issue involving the so-called

189 United States v. Nixon, 418 U.S. 683, 694-95 (1974) (footnotes omitted).

190 In re Grand Jury Investigation, 315 F. Supp. 3d at 652.

$191 I d$.

192 United States v. Concord Mgmt. \& Consulting LLC, 317 F. Supp. 3d 598, 623 (D.D.C. 2018).

193 In re Grand Jury Investigation, 916 F.3d at 1053 (citation omitted).

194 See Brief for the Respondent, Cross-Petitioner at 28-29, United States v. Nixon, 418 U.S. 683 (1974) (Nos. 73-1766, 73-1834) ("The ultimate authority over all executive branch decisions is, under Article II of the Constitution, vested exclusively in the President of the United States. The President has neither waived nor delegated to the Special Prosecutor 
"unitary executive." It does not remotely embrace the statutory status of the special counsel, which is completely irrelevant to the point under discussion. The argument in the Nixon Tapes case would be exactly the same if the Attorney General-or the Deputy Attorney General, or the Solicitor General, or a U.S. Attorney-rather than the special counsel was contesting a presidential assertion of executive privilege. The identity or status of the Department of Justice official does not matter at all. The only nonconstitutional question was whether the President had, as a matter of fact, delegated authority over executive privilege decisions to anyone else (assuming, as a constitutional matter, that such a delegation is permissible). As the President explained in his brief:

[T] he President has not in the past nor does he here challenge those powers that were given to the Special Prosecutor in Watergate-related matters, including the right to conduct grand jury and other investigations, review documentary evidence available, and determine within the confines of the Constitution whom to prosecute and on what charges. Moreover, all decisions relating to the procedural aspects of prosecution including the right to request immunity for any witness are within the scope of his authority. In these and other areas delegated to him, the Special Prosecutor has had and continues to have complete independence.

However, . . . the President has neither waived nor delegated to the Special Prosecutor the President's duty to claim privilege as to all materials, confidential in nature, which fall within the President's inherent authority to refuse to disclose to any executive officer. Nor did Acting Attorney General Bork attempt to delegate such authority to the Special Prosecutor. On the contrary, the authority granted to the Special Prosecutor by then Acting Attorney General Bork in this regard was specifically limited to at most: "determin [ing] whether or not to contest the assertion of executive privilege or any other testimonial privilege.” 38 Fed. Reg. 30,739 (1973).

From this provision, it is abundantly clear that the President has not waived or delegated to the Special Prosecutor his duty to determine within his discretion what executive materials were privileged. Since this decision was retained by the President and falls within the normal scope of his prosecutorial discretion over all criminal cases, the courts are powerless to intervene, even at the request of the Special Prosecutor. ${ }^{195}$

his duty to determine what confidential presidential documents shall be made available to another executive officer."); $i d$. at 41 ("[I]f it is solely an executive decision to prosecute, it follows that the courts are equally powerless to determine what material within the executive branch must be used in the case. Such a decision is exclusively within the power delegated by the Constitution to the Chief Executive . . ..”); id. at 41-42 (“[T] he President has not delegated to the Special Prosecutor or any subordinate official, [sic] his duty to determine the privileged nature and use of executive material. Therefore, the district court plainly erred in asserting that it had jurisdiction to intervene in this suit on the ground that the President was abridging the independence of the Special Prosecutor over matters that were delegated to him. Moreover, it is unnecessary for this Court to speculate on the jurisdictional basis for this suit if the President, had, in fact, delegated his right and responsibilities concerning executive materials to the Special Prosecutor.”).

$195 I d$. at 42-43 (footnote omitted). 
This understanding of the issues in Nixon is confirmed by the government's brief defending the justiciability of the case. The government disputed Nixon's key constitutional "unitary executive" premise of presidential control over law enforcement, maintaining instead that "Congress has vested in the Attorney General, as the head of the Department of Justice, the exclusive authority to conduct the government's civil and criminal litigation, including the exclusive authority for securing evidence." 196 Thus, the issue presented in Nixon involved the relationship between the President and the Department of Justice as an institution, not the relationship between the President and the special counsel. Because the point is so crucial, and because we want there to be no chance that we are misrepresenting the nature or context of the dispute in Nixon, we present the government's argument at length:

We begin by making the fundamental point, overlooked by counsel for the President, that federal criminal prosecutions are brought in the name of the United States of America as a sovereign nation. Despite his extensive powers and even his status as Chief Executive and Chief of State, the President, whether in his personal capacity or his official capacity, is distinct from the United States and is decidedly not the sovereign. Although the Constitution vests the executive power generally in the President (Art. II, Sec. 1), it expressly contemplates the establishment of executive departments which will actually discharge the executive power, with the President's function necessarily limited to "take Care that the Laws be faithfully executed" by other officers of the government (Art. II, Sec. 3). Thus, Article II, Section 2 expressly provides that, instead of giving the President power to appoint (and, perhaps, remove) "inferior Officers" of the Executive Branch, "Congress may by Law vest the Appointment of such inferior Officers, as they think proper, . . . in the Courts of Law, or in the Heads of Departments."

Congress has organized the Department of Justice and provided that the Attorney General is its head. 28 U.S.C. 501, 503. Under Article II, Section 2, Congress has vested in him alone the power to appoint subordinate officers to discharge his powers. 28 U.S.C. 509, 510, 515, 533. Among the responsibilities given by Congress to the Attorney General is the authority to conduct the government's civil and criminal litigation (28 U.S.C. 516):

Except as otherwise authorized by law, the conduct of litigation in which the United States, an agency, or officer thereof is a party, or is interested, and securing evidence therefor, is reserved to officers of the Department of Justice, under the direction of the Attorney General. (Emphasis added.)

As this Court has recognized, this section and companion provisions, see 28 U.S.C. 515-519, "impose on the Attorney General the authority and the duty to protect the Government's interests through the courts." United States v. California, 332 U.S. 19, 27-28. Under this framework it is not the President who has personal charge of the conduct of the government's affairs in court but, rather, it is the Attorney General acting through the officers of the Department of Justice appointed by him. This Court under-

196 Brief for the United States at 17, United States v. Nixon, 418 U.S. 683 (1974) (Nos. 73-1766, 73-1834). 
scored the special status of the officers of the Department of Justice before the courts in Berger $v$. United States, 295 U.S. 78, 88, explaining that the federal prosecutor "is the representative not of an ordinary party to a controversy, but of a sovereignty. ... As such, he is in a peculiar and a very definite sense the servant of the law, the twofold aim of which is that guilt shall not escape or innocence suffer."

Thus, as the district judge below pointedly recognized (Pet. App. 19), the subpoena duces tecum issued by the prosecution to the President is directed to a person who "as a practical matter, is a third party."

It was in the capacity as attorney for the United States that the Special Prosecutor invoked the judicial process. Exercising his exclusive authority under 28 U.S.C. 516 to secure evidence for a pending criminal prosecution within his jurisdiction, the Special Prosecutor is seeking evidence from an adverse party-evidence which the Special Prosecutor has reason to believe is highly material to the trial. Under the law, the Special Prosecutor speaks for the United States in conducting this criminal trial, and under the applicable statutes and regulations he has authority, which can be enforced by the courts, to seek evidence even from the President. Not only is this authority expressly included in the Department of Justice regulations defining his powers (Appendix pp. 146 50, infra), but the record shows that the President personally acceded to the arrangement whereby his assertion of privilege would not preclude the Special Prosecutor, in a proper case, from invoking the judicial process to litigate the validity of the claim. ${ }^{197}$

The accident that it was a special prosecutor rather than a U.S. Attorney or the Attorney General personally who was challenging the President's authority was entirely irrelevant to the jurisdictional issue before the Court in the Nixon Tapes case. Far from a "necessary" step in the Nixon Court's reasoning, the discussion of the special prosecutor's appointment was merely unnecessary (and unhelpful) background.

Second, as dictum, the discussion in Nixon is unpersuasive in the extreme. The Court in Nixon did not examine or even quote the texts of 28 U.S.C. $\$ \S 509,510,515$, and 533 , nor did it compare them to other statutes on the books in 1973 by which Congress vested in other entities like the Department of Agriculture, Education, Health and Human Services, or Transportation the power to appoint inferior officers. ${ }^{198}$ The Court in Nixon did not take notice of the fact that 28 U.S.C. $\$ 515$ (b) refers to employees already "retained" rather than granting a new power to retain inferior officers, nor did it focus on the fact that 28 U.S.C. $\$ 533$ is embedded in the statutes setting up the FBI and refers to prosecutorial and investigative officials, meaning by that term FBI agents and not special counsels who are officers. The Court made no reference at all to 28 U.S.C. $§ 543$, which is the provision that specifically authorizes the (limited) creation and appointment of special counsels but only to assist United States Attorneys as subordinates. Nor did the Court examine the structure of Title 28. Indeed, the Court did

197 Id. at 27-30 (omission in original).

198 We make such a comparison supra, at text accompanying notes 174-78. 
not examine anything at all, which is not surprising, since no party in the case asked it to do so. It is actually very hard to find dicta of less relevance than Nixon's throwaway reference to the statutes purportedly authorizing Department of Justice appointments. The D.C. Circuit's backhanded suggestion that the language in Nixon regarding the statutory scheme for the Department of Justice was "carefully considered language"199 would perhaps be amusing if the rule of law were a laughing matter.

Third, Nixon was written at a time when the Supreme Court's attention to separation of powers and other structural niceties was at its lowest ebb. Since 1974, the Supreme Court's Appointments Clause caselaw has been transformed, most notably by Buckley v. Valeo. ${ }^{200}$ Between 1936 and 1976, the Supreme Court treated the Appointments Clause, as it did other separation of powers provisions, like a dead letter in constitutional law, in much the way it did with the Commerce Clause prior to United States v. Lopez. ${ }^{201}$ This is why the en banc D.C. Circuit in Buckley $v$. Valeo ${ }^{202}$ upheld the constitutionality of a statute which said that two members of the Federal Election Commission would be appointed by the President with the approval of the entire Congress, another two members would be appointed by the Speaker of the House of Representatives, and the final two members would be appointed by the President Pro Tempore of the Senate. ${ }^{203}$ This statute was blatantly unconstitutional under the Appointments Clause of Article II-as blatantly unconstitutional as a statute prescribing that California will henceforth have five senators-but a majority of the D.C. Circuit thought it needed to wait for a riper controversy in order to make that obvious judgment. ${ }^{204}$ The court dismissed references to the text of the Appointments Clause as "strikingly syllogistic." 205 This cavalier treatment of constitutional and statutory texts in separation of powers cases characterized the attitude of the federal courts for four decades following the New Deal.

Since the rebirth of the Appointments Clause in 1976, the Supreme Court has decided a number of additional Appointments Clause cases including: Morrison v. Olson, ${ }^{206}$ Freytag v. Commissioner, ${ }^{207}$ Weiss v. United States, ${ }^{208}$

199 In re Grand Jury Investigation, 916 F.3d 1047, 1053 (D.C. Cir. 2019) (quoting United States v. Fields, 699 F.3d 518, 522 (D.C. Cir. 2012) (internal quotation marks omitted)).

200424 U.S. 1 (1976).

201514 U.S. 549 (1995).

202519 F.2d 821 (D.C. Cir. 1975) (en banc) (per curiam).

203 See 2 U.S.C. § 437c(a) (1) (Supp. IV 1975).

204 See Buckley, 519 F.2d at 890-93. Judge MacKinnon thought it obvious that the appointment process for the FEC was unconstitutional. See id. at 926-33 (MacKinnon, J., concurring in part and dissenting in part).

$205 I d$. at 889 (majority opinion). Some of us were under the impression that syllogisms are generally strong arguments.

206487 U.S. 654 (1988).

207501 U.S. 868 (1991).

208510 U.S. 163 (1994). 
Edmond v. United States, ${ }^{209}$ Free Enterprise Fund v. PCAOB, ${ }^{210}$ and Lucia v. $S E C .{ }^{211}$ The Court today looks at Appointments Clause cases and at issues of governmental structure, notably issues of the internal organization of the executive department, through a very different lens than it did forty-five years ago. Throwaway dicta from the bygone era pre-1976 should have no weight at all. Moreover, the current Supreme Court often relies on clear statement rules in structural constitutional law cases.

United States $v$. Nixon remains precedential caselaw on the justiciability of internal executive department disputes and on the limited scope of executive privilege claims by the President in criminal proceedings against him or her. But to the extent that one regards it as ruling on the legality of Leon Jaworski's appointment (which, as we have seen, it did not), its discussion does not remain good law after the Supreme Court's subsequent careful Appointments Clause decisions in Buckley v. Valeo, in 1976, up through Lucia v. SEC, in 2018. Structure matters today in a way that it did not seem to matter in 1974.

The district courts and D.C. Circuit panel that have addressed this issue recently have been bound by precedent from the D.C. Circuit. One such district court considered itself bound to uphold the appointment of Robert Mueller because of In re Sealed Case,${ }^{212}$ which involved Special Counsel Lawrence Walsh's prosecution of Oliver North in the wake of the Iran-Contra controversy in the mid-1980s. The D.C. Circuit subsequently took the same view. ${ }^{213}$ In re Sealed Case, however, is even less pertinent-if that is possibleto the validity of the Reno Regulations and Mueller's appointment than is United States $v$. Nixon. The validity of the special counsel's appointment was not raised at all in that case.

The judge in Concord Management asserted that the issue of statutory authority to hire Special Counsel Lawrence Walsh was raised by Oliver North "at least at a high level of generality" 214 and was therefore resolved by the D.C. Circuit when that court said in 1987, with no analysis or discussion:

We have no difficulty concluding that the Attorney General possessed the statutory authority to create the Office of Independent Counsel: Iran/ Contra and to convey to it the "investigative and prosecutorial functions and powers" described in 28 C.F.R. $\S 600.1$ (a) of the regulation. The statutory provisions relied upon by the Attorney General in promulgating the regulation are 5 U.S.C. $\S 301$ and 28 U.S.C. $\$ \S 509,510$, and 515. While these provisions do not explicitly authorize the Attorney General to create an Office of Independent Counsel virtually free of ongoing supervision, we read them as accommodating the delegation at issue here. ${ }^{215}$

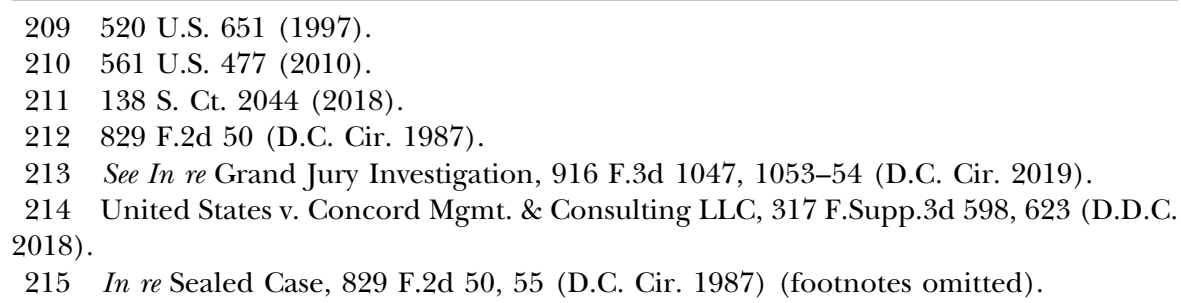


The D.C. Circuit in 2019 said of this discussion:

The issue before the court [in In re Sealed Case] was whether the independent counsel was authorized to investigate and to prosecute officials in regard to the Iran/Contra matter. As such, the Attorney General's authority to appoint an independent counsel was antecedent to deciding whether the Attorney General validly delegated authority to the independent counsel. The court's quoted statements regarding the Attorney General's statutory authority to appoint an independent counsel are, therefore, not dicta . . . .216

Oliver North's only challenge to the statutory authority of the Attorney General to hire Lawrence Walsh stemmed from a "preemption" argument: North claimed that the provisions of the Ethics in Government Act were the exclusive basis for hiring a special counsel and thus foreclosed any parallel authority under other statutes in Title 28 once the Ethics in Government Act provisions were employed. ${ }^{217}$ Absent the provision in 28 U.S.C. $\$ 597$ (a), which said that

$[w]$ henever a matter is in the prosecutorial jurisdiction of an independent counsel or has been accepted by an independent counsel under section 594(e), the Department of Justice, the Attorney General, and all other officers and employees of the Department of Justice shall suspend all investigations and proceedings regarding such matter, except to the extent required by section 594(d)(1), and except insofar as such independent counsel agrees in writing that such investigation or proceedings may be continued by the Department of Justice, ${ }^{218}$

North said that he would have no objection to the Attorney General's statutory authority: "[A]s long as the [Ethics] Act remains in force, ... the Attorney General ha[s] no independent authority" to act in this matter, ${ }^{219}$ and "the regulation [creating the Office of Special Counsel] might provide a source of authority if and when the Ethics Act is ruled unconstitutional."220 North's other statutory arguments ran to whether the Office of Special Counsel could be located outside the Department of Justice, ${ }^{221}$ which is obviously not pertinent to the issues that we raise here, and whether the hiring of associate counsels for the special counsel had followed the appropriate procedures under 28 U.S.C. $§ 515$ for commissioning lawyers. ${ }^{222}$

We urge anyone genuinely interested in this question (and one might have hoped that the D.C. Circuit panel hearing In re Grand Jury Investigation would fall into this category) to read in full the brief and reply brief of Colonel North in In re Sealed Case. It is obvious from those documents that the only statutory challenge to Special Counsel Walsh's appointment, as opposed

216 In re Grand Jury Investigation, 916 F.3d at 1054.

217 See Brief of Appellant at 13-21, In re Sealed Case, 829 F.2d 50 (No. 87-5247).

21828 U.S.C. $\$ 597$ (a) (2012).

219 See Brief of Appellant, supra note 217, at 20 (emphasis added).

$220 I d$. at 35.

221 See Reply Brief of Appellant at 43-54, In re Sealed Case, 829 F.2d 50 (No. 87-5247).

222 See Brief of Appellant, supra note 217, at 21-33. 
to the location of Special Counsel Walsh's authority outside the Department of Justice, was based on $\S 597$ (a). As for why the D.C. Circuit in In re Sealed Case would have chosen to opine, in unexplained dicta, on a matter not presented by the case-we leave that speculation to others.

In sum, the statutes purportedly authorizing Mueller to act as special counsel do no such thing, and no appellate case prior to 2019 holds otherwise.

\section{The Constitution Does Not Permit Appointment as an Inferior Officer of a Special Counsel with Robert Mueller's Scope OF Authority}

Even if there was statutory authority for the appointment of special counsels who replace rather than assist U.S. Attorneys, the 1999 Reno Regulations and the creation of Mueller's office and his appointment to it would still be invalid. The Constitution requires that all noninferior "Officers of the United States" be appointed through presidential nomination and senatorial confirmation. The 1999 Reno Regulations contemplate the creation of special counsels appointed by the Attorney General. ${ }^{223}$ That is a constitutionally permissible form of appointment for inferior officers if Congress so directs, as inferior officers may be appointed by the President alone, the courts of law, or department heads if Congress so provides "by Law." 224 We have shown in Part II, however, that the relevant statutes for the Department of Justice do not contain any such congressional direction. But even if they did contain such authorizations, the special counsels contemplated by the Reno Regulations are not inferior officers. They are supercharged U.S. Attorneys. Robert Mueller, in particular, was most emphatically not an inferior officer as he claimed to be, and he therefore needed to be either an employee of the Justice Department (in which case he could not exercise most of his functions) or a superior officer appointed by the President with the advice and consent of the Senate, in the same way that Patrick Fitzgerald was appointed as special counsel.

The constitutionally proper form of appointment for a special counsel is clear as a matter of original meaning. The inferiority of an officer under the Constitution is a function both of the officer's location in a decision-making hierarchy and of the officer's scope of authority. An officer whose decision is hierarchically final within the executive department (apart from the omnipresent possibility of presidential review) cannot be inferior regardless of the nature and character of the officer's authority. But even an officer whose decision is subject to review by another officer can still be noninferior if the officer's authority is sufficiently broad. Special counsels under the 1999 Reno Regulations exercise the full power of U.S. Attorneys, and U.S. Attorneys have broad enough authority to preclude them from being inferior officers.

223 See Reno Regulations, supra note 57.

224 U.S. Const. art. II, § 2, cl. 2. 
Moreover, even under the Supreme Court's faulty reasoning in Morrison v. Olson, which considers a multitude of factors in distinguishing inferior from noninferior officers, ${ }^{225}$ Robert Mueller was not an inferior officer. The nature and scope of his authority differed in important ways from the nature and scope of the authority of independent counsel Alexia Morrison, whose appointment as an inferior officer was (we think wrongly) upheld in Morrison. ${ }^{226}$ Furthermore, some lower courts have wildly overread the Supreme Court's decision in Edmond v. United States ${ }^{227}$ to establish a rule that any degree of internal executive department supervision is enough to make an officer inferior. That is a position so absurd that no honest reader could possibly attribute it to Justice Scalia's opinion in Edmond. Whether viewed from the standpoint of constitutional meaning or caselaw, Robert Mueller's appointment by the (acting) Attorney General was constitutionally defective.

We show in Section III.A below that Robert Mueller was not an employee and in Section III.B below that he was not, as he needed to be, properly appointed as a superior officer.

\section{A. Robert Mueller Was an Officer of the United States and Not an Employee}

We have thus far taken for granted that special counsels appointed under the Reno Regulations, and Robert Mueller in particular, are "Officers of the United States" for purposes of the Appointments Clause. If that assumption is false, and special counsels are not officers, then the only legal questions about their appointments are statutory. As Justice Kagan aptly put it, if government workers are "part of the broad swath of 'lesser functionaries' in the Government's workforce . . . , the Appointments Clause cares not a whit about who named them."228 The Department of Justice since 1999 has proceeded on the assumption that special counsels are constitutional officers, and it (rightly) does not contest Robert Mueller's officer status in any of the cases that challenge his authority to act. ${ }^{229}$ Nonetheless, it is worth taking a moment to clarify how and why special counsels are officers, as it will set the context for the decidedly contested question whether they are inferior or noninferior officers.

The Supreme Court addressed the issue of who is an officer of the United States rather than merely an employee in Buckley $v$. Valeo, ${ }^{230}$ where it held that members of the Federal Election Commission, who were clearly not appointed in conformance with the Appointments Clause, ${ }^{231}$ could "properly perform duties only in aid of those functions that Congress may carry out

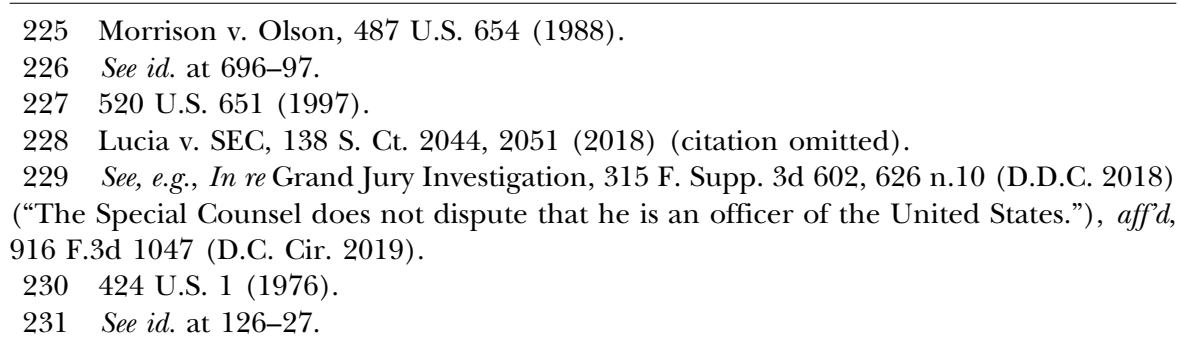


by itself, or in an area sufficiently removed from the administration and enforcement of the public law as to permit their being performed by persons not 'Officers of the United States.'"232 Thus, explained the Court, "provisions of the [Federal Election Campaign] Act [of 1971], vesting in the Commission primary responsibility for conducting civil litigation in the courts of the United States for vindicating public rights, violate Art. II, $§ 2, \mathrm{cl}$. 2, of the Constitution. Such functions may be discharged only by persons who are 'Officers of the United States' within the language of that section."233

Buckley v. Valeo thus makes crystal clear what should have been clear from 1788 onwards: civil and criminal litigation can only be conducted by the United States government through officers of the United States and not through mere employees. Employees, of course, can play a role in those proceedings; officers need not gather every piece of evidence, argue every motion, or attend every deposition. But the basic decisions whether and how to proceed with legal action must be made, in the final analysis, by officers of the United States. Since Special Counsel Robert Mueller conducted criminal litigation in federal court by deciding who to charge, who to seek to indict, and who to prosecute, he cannot be merely an employee of the federal government.

This is roundly confirmed by the Supreme Court's decision in Lucia v. $S E C,{ }^{234}$ which held that administrative law judges (ALJs) of the Securities and Exchange Commission (SEC) are constitutional officers because they (1) take testimony, (2) receive evidence and examine witnesses including taking depositions, (3) conduct trials and administer oaths, (4) make decisions on the admissibility of evidence, (5) issue subpoenas, and (6) have the power to punish contumacious conduct. ${ }^{235}$ Seven justices of the Supreme Court in Lucia thus had little trouble determining that the SEC's administrative law judges were officers of the United States and not mere employees. Special Counsel Robert Mueller has exercised the power to (1) conduct criminal investigations anywhere in the United States and to convene grand juries; ${ }^{236}$ (2) indict U.S. citizens, as well as thirteen Russian citizens and three Russian corporate entities, thus affecting U.S. foreign policy significantly; ${ }^{237}$ (3) seek revocation of bail and the incarceration before trial of one U.S. citizen, Paul

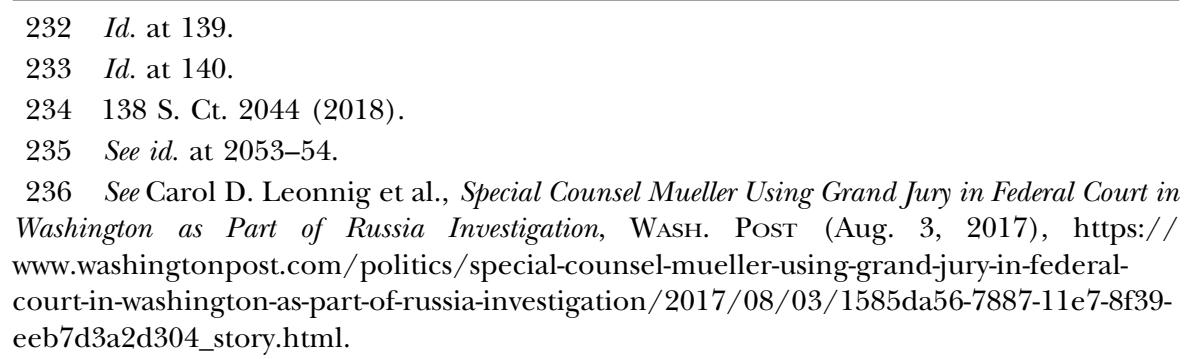

236 See Carol D. Leonnig et al., Special Counsel Mueller Using Grand Jury in Federal Court in Washington as Part of Russia Investigation, WASH. Post (Aug. 3, 2017), https:// www.washingtonpost.com/politics/special-counsel-mueller-using-grand-jury-in-federalcourt-in-washington-as-part-of-russia-investigation/2017/08/03/1585da56-7887-11e7-8f39eeb7d3a2d304_story.html.

237 See Karen Yourish et al., Everyone Who's Been Charged in Investigations Related to the 2016 Election, N.Y. Times, https://www.nytimes.com/interactive/2018/08/21/us/muellertrump-charges.html? mtrref=www.google.com\&gwh=1C82584C4BDC79F397BB700B73B07 859\&gwt=pay\&assetType=REGIWALL (last updated May 23, 2019). 
Manafort; ${ }^{238}$ (4) investigate alleged obstruction of justice by the President of the United States; ${ }^{239}$ (5) accept guilty pleas; ${ }^{240}$ (6) interview top White House aides and request documents ordinarily protected by executive privilege;241 (7) take testimony under oath and indict witnesses for lying to him;242 and (8) issue subpoenas and question private citizens. ${ }^{243}$

As the Supreme Court said in Buckley v. Valeo, "[i]f a postmaster first class, Myers v. United States, 272 U. S. 52 (1926), and the clerk of a district court, Ex parte Hennen, 13 Pet. 230 (1839), are inferior officers of the United States within the meaning of the Appointments Clause, as they are," 244 then surely an official exercising the power wielded by Robert Mueller is at least such an officer as well. We are aware of only three possible bases for disagreement with this conclusion, and none is persuasive.

First, Justice Breyer would not have reached the constitutional issue in Lucia but would instead have decided the case on statutory grounds; the statutory provision for appointment of ALJs prescribed that appointments would be made by the "agency," ${ }^{245}$ which Justice Breyer took to mean "the Commission itself" rather than Commission staff or other lower-level functionaries. ${ }^{246}$ As a constitutional matter, however, Justice Breyer insisted that "the Appointments Clause is properly understood to grant Congress a degree of leeway as to whether particular Government workers are officers or instead mere employees not subject to the Appointments Clause."247 To some extent, that is clearly true, if all that is meant is that Congress can control whether someone is an officer by giving them more or fewer duties. But we think that Justice Breyer means something more than this. There is no doubt, for instance, that ALJs exercise a scope of authority more than sufficient to make them constitutional officers. We have always thought it somewhat mysterious that it took until 2018 for that proposition to be settled in the law. Justice Breyer, however, seems to think that if Congress specifically says by statute

238 See Matt Apuzzo, Mueller Accuses Paul Manafort of Attempted Witness Tampering, N.Y. Times (June 4, 2018), https://www.nytimes.com/2018/06/04/us/politics/paul-manafortmueller-witness-tampering.html.

239 See Michael S. Schmidt et al., Mueller Is Said to Seek Interviews with West Wing in Russia Case, N.Y. Times (Aug. 12, 2017), https://www.nytimes.com/2017/08/12/us/politics/ mueller-trump-russia-priebus.html.

240 See Ryan Teague Beckwith, Here Are All of the Indictments, Guilty Pleas and Convictions From Robert Mueller's Investigation, TIME (March 22, 2019), https://time.com/5556331/ mueller-investigation-indictments-guilty-pleas/.

241 See Schmidt et al., supra note 239.

242 See Yourish et al., supra note 237.

243 See Mark Hosenball, Mueller Issues Grand Jury Subpoenas to Trump Adviser's Social Media Consultant, Reuters (May 16, 2018), https://www.reuters.com/article/us-usa-trump-muel ler/mueller-issues-grand-jury-subpoenas-to-trump-advisers-social-media-consultant-idUSKC N1IH2OB.

244 Buckley v. Valeo, 424 U.S. 1, 126 (1976).

245 5 U.S.C. $\$ 3105$ (2012).

246 Lucia v. SEC, 138 S. Ct. 2044, 2057-58 (2018) (Breyer, J., concurring in the judgment in part and dissenting in part).

247 Id. at 2062. 
that ALJs are not officers, with no change in their actual authority, this might be enough to make them employees rather than officers. Perhaps a similar congressional pronouncement about special counsels would lead him to the same conclusion.

Stated this baldly, we think the position is plainly wrong. An officer is not someone with a fancy title and a commission. Officers have fancy titles and commissions because they perform functions that make them officers. According to Buckley, someone is an officer if they "exercis[e] significant authority pursuant to the laws of the United States." 248 Recent scholarship suggests, as a matter of original meaning, a broader understanding of "officer," under which anyone is an officer "whom the government entrusts with ongoing responsibility to perform a statutory duty of any level of importance" 249 - meaning essentially that officers are people who exercise nontrivial rather than, as Buckley would have it, significant governmental authority. In either case, the label follows the function rather than vice versa-just as entities are government agencies, and thus subject to constitutional requirements, by virtue of their real-world activities rather than legislative labels. It is clear, for example, that Amtrak is an agency subject to the First Amendment notwithstanding Congress's declaration that Amtrak "will not be an agency . . . or establishment of the United States Government."250 As the Supreme Court explained, this statute

is assuredly dispositive of Amtrak's status as a Government entity for purposes of matters that are within Congress's control-for example, whether it is subject to statutes that impose obligations or confer powers upon Government entities, such as the Administrative Procedure Act, the Federal Advisory Committee Act, and the laws governing Government procurement .... But it is not for Congress to make the final determination of Amtrak's status as a Government entity for purposes of determining the constitutional rights of citizens affected by its actions. If Amtrak is, by its very nature, what the Constitution regards as the Government, congressional pronouncement that it is not such can no more relieve it of its First Amendment restrictions than a similar pronouncement could exempt the Federal Bureau of Investigation from the Fourth Amendment. ${ }^{251}$

Similarly, while the Sarbanes-Oxley Act says that the Public Company Accounting Oversight Board (PCAOB) "shall not be an agency or establishment of the United States Government" and "[n]o member or person employed by, or agent for, the Board shall be deemed to be an officer or employee of or agent for the Federal Government by reason of such ser-

248 Buckley, 424 U.S. at 126.

249 Jennifer L. Mascott, Who Are "Officers of the United States"?, 70 Stan. L. Rev. 443, 454 (2018); see also James C. Phillips et al., Corpus Linguistics and "Officers of the United States, " 42 Harv. J.L. \& Pub. Pol'y 871, 873 (2019) (concluding that "the linguistic landscape" of the original meaning of "Officers of the United States" is "messy, but more in line with Professor Mascott's proffered definition than the Supreme Court's ahistorical one”).

25045 U.S.C. $\$ 541$ (1988).

251 Lebron v. Nat'l R.R. Passenger Corp., 513 U.S. 374, 392 (1995) (citations omitted). 
vice," 252 that pronouncement "is about as interesting and profound as would be a similar legislative declaration that, for example, FBI agents are not government officials for purposes of the Fourth Amendment."253 In fact, the Supreme Court in Free Enterprise Fund v. $\mathrm{PCAOB}^{254}$ gave that congressional declaration no notice at all when applying the Constitution's separation-ofpowers provisions to the PCAOB. By the same token, the content of the term "Officers of the United States" is a matter of constitutional law. Congress is free to opine on that matter, as it is free to opine on anything, but other departments are free to give that legislative opinion on constitutional meaning as much or as little weight as they wish. The Constitution means what it means, not what Congress (or any other institution) says that it means.

It is possible that Justice Breyer meant nothing more than that courts, as a matter of judicial policy, should defer to the views of Congress in close cases involving the actual constitutional meaning of the term "Officers of the United States." 255 This would go to the issue of judicial discretion rather than constitutional meaning, and it raises topics far beyond the scope of this Article. We note only that while legislative and executive interpretations of the Constitution are, in principle, equivalent to, and just as deserving of deference as, judicial interpretations, deference to another actor is normally justified by reasons of legitimacy (the other actor is deemed politically, even if not legally, more appropriate as a decisionmaker); accuracy (the other actor is more likely than the deferring actor to get the right answer): economics (deferring is cheaper than deciding for yourself); signaling (the deferring actor is communicating something to another actor by deferring); or strategy (the deferring actor gains prestige or legal capital by deferring). ${ }^{256}$ This is a case-specific inquiry, though it is possible that categorical judgments about classes of cases might be reasonable in the right circumstances. In this specific instance, it is not obvious how any or all of these considerations warrant deference to congressional judgments about who is an "Officer of the United States," though we can imagine a case being built for such deference. We believe, however, that the correct answer in this instance is clear enough so that deference to any actor would not change the outcome.

Second, law professors Seth Barrett Tillman and Josh Blackman have argued that Lucia and other Supreme Court caselaw establishes that officers

25215 U.S.C. $\$ 7211$ (b) (2012).

253 Gary Lawson, The "Principal" Reason Why the PCAOB Is Unconstitutional, 62 VAND. L. Rev. En Banc 73, 74-75 (2009).

254561 U.S. 477 (2010).

255 See Lucia v. SEC, 138 S. Ct. 2044, 2062 (2018) (Breyer, J., concurring in the judgment in part and dissenting in part) ("Congress' intent in this specific respect is often highly relevant. Congress' leeway is not, of course, absolute-it may not, for example, say that positions the Constitution itself describes as 'Officers' are not 'Officers.' But given the constitutional language, the Court, when deciding whether other positions are 'Officers of the United States' under the Appointments Clause, should give substantial weight to Congress' decision.").

256 See Gary Lawson \& Guy I. Seidman, Deference: The Legal Concept and the Legal Practice (2019). 
must, at a minimum, occupy a "continuing" office. ${ }^{257}$ Because special counsels are appointed only to perform specific, limited tasks and do not have permanent, enduring positions, the argument is that they cannot be officers but can only be employees. ${ }^{258}$ If that position is correct, then our argument here is even stronger than we think it is. Employees can only exercise powers and perform functions appropriate to employees. Those powers and functions do not include all of the powers and functions of U.S. Attorneys, which is what the Reno Regulations prescribe for special counsels. ${ }^{259}$ If those counsels really are mere employees, virtually everything that they do is unlawful, and any argument beyond that point about the legality of Mueller's actions is unnecessary. But we do not think that this position is correct.

To be sure, Professors Tillman and Blackman, who specifically disavow any intention of making claims about original meaning, make a plausible case based on the language of Lucia $^{260}$ and decisions that came before it. In United States v. Germaine, for example, the Court said that "the term ['Officer of the United States'] embraces the ideas of tenure, duration, emolument, and duties, and that the latter were continuing and permanent, not occasional or temporary."261 The Office of Legal Counsel (OLC) also emphasized the "continuing" nature of an office in 2007 when it sought to synthesize two centuries of caselaw concerning officer status. ${ }^{262}$ The idea that lack of continuity in a position precludes officer status, for example,

explains away cases such as Auffmordt $v$. Hedden, in which a merchant engaged by the Customs Service to appraise the value of imported goods was not considered an officer; the many historical situations in which special agents or envoys have been used in diplomatic missions without going through the constitutional appointments process; and the long tradition of qui tam litigation, in which private citizens can, in a limited fashion, sue on behalf of the United States and collect bounties. ${ }^{263}$

But while this may suffice to establish that anyone who holds a continuing position ought to be considered an officer, which would be consistent with Professor Jenn Mascott's findings about the original meaning of the Appointments Clause, ${ }^{264}$ it does not establish the converse. As the OLC explained, "a temporary position also may be continuing, if it is not personal, 'transient,'

257 Seth Barrett Tillman \& Josh Blackman, Is Robert Mueller an 'Officer of the United States' or an 'Employee of the United States'?, LAwFARE (July 23, 2018), https:/ / www.lawfareblog.com/ robert-mueller-officer-united-states-or-employee-united-states.

258 See id.

259 See Reno Regulations, supra note 57.

260 See Lucia v. SEC, 138 S. Ct. 2044, 2051 (2018).

261 United States v. Germaine, 99 U.S. 508, 511-12 (1879).

262 See Officers of the United States Within the Meaning of the Appointments Clause, 31 Op. O.L.C. 73, 73-74 (2007) [hereinafter Officers of the United States] ("[A] position, however labeled, is in fact a federal office if (1) it is invested by legal authority with a portion of the sovereign powers of the federal Government, and (2) it is 'continuing." ). 263 Gary Lawson, Federal Administrative Law 201 (8th ed. 2019) (citation omitted).

264 See Mascott, supra note 249. 
or "incidental." "265 Specifically, "[f] or example, the position of Attorney General presumably still would be an office if Congress provided for it to expire each year but reauthorized it annually."266 Special counsels under the Reno Regulations do not have the permanence of a statutorily authorized office such as the Attorney General, ${ }^{267}$ but neither is the position personal, transient, or incidental, such as the position of a special envoy. The regulations describe the nature and character of the position, not the identity of the person who holds it. ${ }^{268}$ Today it is Robert Mueller; previously it was Patrick Fitzgerald (or former Senator John Danforth); tomorrow it could be Jeff Sessions. Nor is it transient, like a one-time diplomatic endeavor or a shortterm contract to value imported goods. Mueller served for almost two years. And to call a position that exercises all of the powers of a U.S. Attorney "incidental" is ridiculous. Accordingly, notwithstanding some incidental (and perhaps transient?) dicta in Supreme Court opinions, we think it clear that the special counsel is an "Officer of the United States."

Third, Justices Sotomayor and Ginsburg in Lucia "would hold that one requisite component of 'significant authority' is the ability to make final, binding decisions on behalf of the Government. Accordingly, a person who merely advises and provides recommendations to an officer would not herself qualify as an officer."269 ALJs are not officers under this standard because their decisions can be reviewed and overruled by the commissions or agencies for which they work. ${ }^{270}$ This approach, however, badly confuses the distinction between inferior and noninferior officers with the distinction between employees and officers. The Solicitor General and the Deputy Attorney General, for example, can be reviewed and overruled by the Attorney General, in whom is vested all powers in the Department of Justice. ${ }^{271}$ Does that mean that the Solicitor General and Deputy Attorney General are not even "Officers of the United States"? With all respect, we do not think that Justices Sotomayor and Ginsburg, and the law clerks that advised them, thought this through very carefully.

Accordingly, special counsels appointed under the Reno Regulations are clearly "Officers of the United States" who must be appointed in conformance with the Appointments Clause. The only real question is whether they can constitutionally be appointed by a department head rather than by the President with the advice and consent of the Senate (assuming that Congress enacts a statute permitting this mode of appointment). The answer is no.

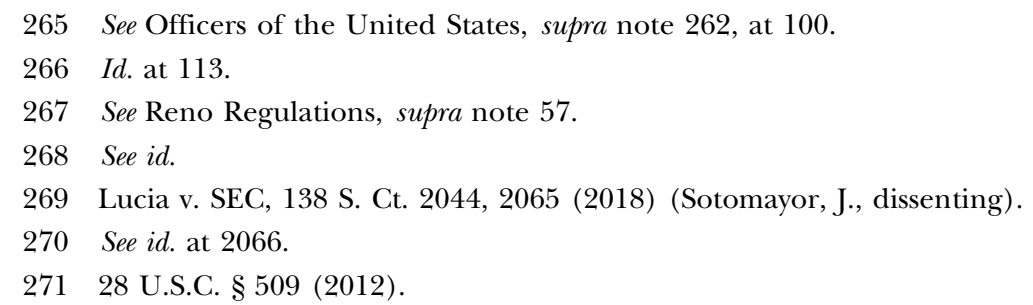




\section{B. Robert Mueller Was a Superior Officer of the United States}

It is helpful at this point to return again to the actual words of the constitutional text. The Appointments Clause provides again that the President

shall nominate, and by and with the Advice and Consent of the Senate, shall appoint Ambassadors, other public Ministers and Consuls, Judges of the supreme Court, and all other Officers of the United States, whose Appointments are not herein otherwise provided for, and which shall be established by Law: but the Congress may by Law vest the Appointment of such inferior Officers, as they think proper, in the President alone, in the Courts of Law, or in the Heads of Departments. ${ }^{272}$

If an officer is not "inferior," the Constitution leaves no wiggle room: noninferior officers must be appointed by presidential nomination and senatorial confirmation. The Reno Regulations can only pass a laugh test for constitutionality if special counsels are inferior officers.

We do not speculate here about whether it would be possible for Congress to create a special counsel who is constitutionally an "inferior" officer. Perhaps it would, if the person's duties were sufficiently limited and were subject to supervision, direction, control, and firing at will by a superior officer. The existing 1999 Reno Regulations, however, specify that special counsels exercise all powers of U.S. Attorneys. ${ }^{273}$ That is enough to make them noninferior. And even if one takes account of the faulty reasoning in Morrison v. Olson, Robert Mueller was a noninferior officer under existing caselaw.

\section{Principal Officers Are a Subset of Superior Officers}

Before we make that case, however, we need to clear up a terminological point that has created some confusion in the lower courts that have considered challenges to Robert Mueller's appointment. The Appointments Clause speaks of "Officers of the United States," and then carves out a category of "inferior" officers who can be appointed without presidential nomination and senatorial confirmation. The Constitution does not use any specific term to describe those noninferior officers who must, regardless of Congress's wishes, be appointed through presidential nomination and senatorial confirmation. It is conventional today to describe those noninferior officers as "principal" officers. ${ }^{274}$ Apart from an ambiguous reference in $1867,{ }^{275}$ we believe that this terminology first appeared in the Supreme Court in 1976 in

272 U.S. Const. art. II, § 2, cl. 2.

273 See Reno Regulations, supra note 57.

274 See, e.g., In re Grand Jury Investigation, 916 F.3d 1047, 1052 (D.C. Cir. 2019) ("As interpreted by the Supreme Court, the Appointments Clause distinguishes between 'principal officers,' who must be nominated by the President with advice and consent of the Senate, and 'inferior officers,' who may be appointed by the President alone, or by heads of departments, or by the judiciary, as Congress allows.").

275 See United States v. Hartwell, 73 U.S. (6 Wall.) 385, 395 (1867). 
Buckley $v$. Valeo. ${ }^{276}$ Whatever its origins, the terminology is a mistake that has the potential badly to mislead.

The term "principal Officer" does not appear in the Appointments Clause, though it does appear in two other constitutional provisions. First, the Opinions Clause says that the President "may require the Opinion, in writing, of the principal Officer in each of the executive Departments, upon any Subject relating to the Duties of their respective Offices." 277 The phrasing of the Opinions Clause indicates that there is one and only one "principal" officer in each department, meaning that the "principal" officers are really the "Heads of Departments" who are capable of appointing inferior officers (or the chair of a multimember commission if such a commission can be a constitutional "Department" with a collegial "Head[ ]" as an appointing authority). ${ }^{278}$ Second, the Twenty-Fifth Amendment says:

Whenever the Vice President and a majority of either the principal officers of the executive departments or of such other body as Congress may by law provide, transmit to the President pro tempore of the Senate and the Speaker of the House of Representatives their written declaration that the President is unable to discharge the powers and duties of his office, the Vice President shall immediately assume the powers and duties of the office as Acting President. ${ }^{279}$

This provision also implies that there is exactly one principal officer in each department.

This does not mean that all nonprincipal officers are inferior officers for purposes of the Appointments Clause. The residual counterpart to an inferior officer is a superior officer, and many superior officers are not principal officers. This was very clear at the Constitutional Convention. When the inferior officers provision of the Appointments Clause was introduced by Gouverneur Morris on September 15, 1787, James Madison claimed: "It does not go far enough if it be necessary at all-Superior Officers below Heads of Departments ought in some cases to have the appointment of lesser offices." 280 Madison clearly had the understanding that the class of "Superior Officers" was broader than the class of department heads (or "principal Officers"). This distinction (contra the unfounded and uninformed observation of a district court judge that "there is little indication that anyone at the Convention but [Gouverneur] Morris agreed with Madison”) ${ }^{281}$ was recognized by others at the Constitutional Convention as well. Rufus King, in discussing the Senate's role in appointments, "did not suppose it was meant that

276424 U.S. 1, 132 (1976) ("Principal officers are selected by the President with the advice and consent of the Senate. Inferior officers Congress may allow to be appointed by the President alone, by the heads of departments, or by the Judiciary.”).

277 U.S. Const. art. II, § 2, cl. 1.

278 See United States v. Germaine, 99 U.S. 508, 511 (1879).

279 U.S. Const. amend. XXV, § 4.

2802 Records of the Federal Convention, supra note 72, at 627.

281 In re Grand Jury Investigation, 315 F. Supp. 3d 602, 646 (D.D.C. 2018), aff'd, 916 F.3d 1047 (D.C. Cir. 2019). 
all the minute officers were to be appointed by the Senate, or any other original source, but by the higher officers of the departments to which they belong." 282 Whether one calls them "superior" or "higher" officers, the Framers distinguished more important from less important officers, and the scheme of appointment was based upon that distinction.

Thus, there are actually three categories of officers created by the Constitution: (1) principal officers who are the heads of departments, who can be compelled by the President to give opinions in writing, and who must participate in deliberations over the President's disability to serve under the Twenty-fifth Amendment; (2) superior (or "higher") officers who include ambassadors, other public ministers and consuls, Justices of the Supreme Court (and judges of the inferior federal courts), deputy cabinet secretaries, assistant cabinet secretaries, and permanent U.S. Attorneys; and, finally, (3) inferior (or "minute") officers whose appointments Congress can by law vest in the President alone, the courts of law, and the heads of departments.

The discussions of the Appointments Clause at the Philadelphia Constitutional Convention were almost exclusively about the appointment of officers nominated by the President and confirmed by the Senate. For example, Gouverneur Morris said on September 7, 1787, shortly before Rufus King's remarks quoted above: "[T] hat as the President was to nominate, there would be responsibility, and as the Senate was to concur, there would be security." 283 There was significant discussion at the Convention about the appointment process for superior officers, but only one very brief meaningless and perfunctory conversation about the process for appointing inferior officers on September 15, 1787: "The motion being lost by the equal division (of votes,) It was urged that it be put a second time, some such provision being too necessary, to be omitted, and on a second question it was agreed to nem. con." 284 Obviously, the Founders' Constitution envisioned a world where superior officers would be very powerful and inferior officers would be less significant.

The same understanding emerges from The Federalist, which says:

It will be agreed on all hands that the power of appointment, in ordinary cases can be properly modified only in one of three ways. It ought either to be vested in a single man, or in a select assembly of a moderate number, or in a single man with the concurrence of such an assembly. . . .

The sole and undivided responsibility of one man will naturally beget a livelier sense of duty and a more exact regard to reputation. . . .

... [T] he necessity of the [Senate's] concurrence [in nominations] would have a powerful, though, in general, a silent operation. It would be

2822 Records of the Federal Convention, supra note 72, at 539 (statement of Rufus King) (emphasis added).

$283 I d$.

$284 I d$. at $627-28$. 
an excellent check upon a spirit of favoritism in the President, and would tend greatly to prevent the appointment of unfit characters from State prejudice, from family connection, from personal attachment, or from a view to popularity. ${ }^{285}$

Again, nothing at all is said about the inferior officer proviso in the Appointments Clause, while there is extensive discussion of appointment by presidential nomination and senatorial consent. The same is evident again in The Federalist No. 77, which also discusses the provisions for presidential nomination and senatorial consent while ignoring the inferior officer proviso. ${ }^{286}$ It is obvious that the Founders' Constitution never contemplated inferior officers exercising as much power as does a special counsel with the full powers of a U.S. Attorney.

\section{United States Attorneys, Inter Alia, Are Superior Officers}

A world in which officers such as special counsels are inferior officers bears no resemblance to the actual practice of the United States government as it has functioned for 231 years, from 1788 to 2019. No Attorney General has ever claimed the power to appoint a whole shadow Justice Department composed only of inferior officers, and such a claim would raise serious civil liberties and federalism issues. Moreover, Congress has from 1789 on assumed that cabinet secretaries, permanent U.S. Attorneys, and lower federal court judges must be superior officers nominated by the President and confirmed by the Senate.

If one thinks that Justice Breyer is right that some measure of deference to Congress on the meaning of constitutional provisions regarding appointments is appropriate ${ }^{287}$ : Congress has in hundreds of statutes passed over the last 230 years helped elucidate, or liquidate, the meaning of the Appointments Clause by specifying, statutorily, which officers are superior officers and which are inferior officers. These framework statutes enacted by Congress and signed into law by the President are legislative and executive department determinations as to where the constitutional line falls between superior officers and inferior officers, and as a matter of first principles those views are as significant as are rulings of the Supreme Court. ${ }^{288}$ Congress's

285 The Federalist No. 76, 370-72 (Alexander Hamilton) (Jim Miller ed., 2014) (first emphasis added).

286 The Federalist No. 77, 375 (Alexander Hamilton) (Jim Miller ed., 2014) ("The blame of a bad nomination would fall upon the President singly and absolutely. The censure of rejecting a good one would lie entirely at the door of the Senate . . . If an ill appointment should be made, the executive, for nominating, and the Senate, for approving, would participate, though in different degrees, in the opprobrium and disgrace.").

287 See supra note 255 and accompanying text.

288 The literature and history of this "departmentalism" account of constitutional interpretation is too voluminous even for string citation. For the thoughts of one of us on the matter, see Gary Lawson, Interpretative Equality as a Structural Imperative (Or "Pucker Up and Settle This!"), 20 Const. Comment. 379, 380 (2003); Lawson \& Moore, supra note 79 at 1270 . 
longstanding statutory regime under which deputy cabinet secretaries, assistant cabinet secretaries, and permanent U.S. Attorneys are superior officers is, for those who believe in such things, ${ }^{289}$ a constitutional construction reflecting long-standing settled practice on which hundreds of millions of people have relied for 230 years. Since the Judiciary Act of 1789, U.S. district court judges, U.S. District Attorneys (today called U.S. Attorneys), and U.S. Marshals have all been treated as superior officers whose appointments require presidential nomination and senatorial consent.

The definitive work on the history of the U.S. Department of Justice is Homer Cummings and Carl McFarland's Federal Justice: Chapters in the History of Justice and the Federal Executive. ${ }^{290}$ The authors explain that provision for both the Attorney General of the United States and for the District Attorneys, as the present U.S. Attorneys were initially called, was made in section 35 of the Judiciary Act of 1789. That Act required that both the Attorney General and the District Attorneys be "person[s] learned in the law."291 The District Attorneys were to act in each district of the United States which had a district court "as attorney for the United States . . . to prosecute . . . all delinquents for crimes and offences, cognizable under the authority of the United States, and all civil actions in which the United States shall be concerned." ${ }^{992}$ Cummings and McFarland note that "the Judiciary Act in its final form left the appointment of both the Attorney General and the district attorneys to the President and Senate."293

Homer Cummings, who was President Franklin Roosevelt's Attorney General from 1933 to 1939, recognized that every Congress since 1789 has been of the view that U.S. Attorneys had to be nominated by the President and confirmed by the Senate. Thus, the Senate Executive Journal indicates that the Senate passed the Judiciary Act of 1789 on September 24, 1789, and that very same day President George Washington immediately nominated six persons to the U.S. Supreme Court, as well as a number of District Attorneys and U.S. Marshals. ${ }^{294}$ One day later, on September 25, 1789, President Washington nominated a district judge, a District Attorney, and a Marshal for New Jersey and New York, as well as nominating a Secretary of State, an Attorney General, and a Postmaster General. ${ }^{295}$ Two days after passing the Judiciary Act of 1789, on September 26, 1789, the Senate advised and consented to all six of the President's Supreme Court nominees and to the district judge, District attorney, and Marshal for the Districts of Maine, New Hampshire, Massa-

289 The authors of this Article do not fully agree on the appropriate weight to be given to long-settled legislative and executive practices.

290 See generally Homer Cummings \& Carl McFarland, Federal Justice (1937).

291 Judiciary Act of 1789, ch. 20, § 35, 1 Stat. 73, 92.

$292 I d$.

293 Cummings \& McFarland, supra note 290, at 18.

294 See 1 Journal of the Executive Proceedings of the Senate of the United States of America 29 (Washington, D.C., Duff Green 1828) [hereinafter Journal of the Executive Proceedings].

295 See id. at 32-33. 
chusetts, Connecticut, Pennsylvania, Delaware, Maryland, Virginia, South Carolina, Georgia, Kentucky, New York, and New Jersey. ${ }^{296}$ Only after the Senate had advised and consented to the District Attorney nominees did the Senate turn to President Washington's cabinet nominations. The Senate then advised and consented to the nominations of Thomas Jefferson to be Secretary of State, Edmund Randolph to be Attorney General, and Samuel Osgood to be Postmaster General. ${ }^{297}$

The very same day, on September 26, 1789, President Washington signed Richard Harrison's commission appointing him to be the first District Attorney for the District of New York. ${ }^{298}$ Sixty people have been nominated by the President and confirmed by the Senate between 1789 and 2014 to be the U.S. Attorney, first for the District of New York, and then for what was called the Southern District of New York. ${ }^{299}$ Throughout this 225-year period of time, all sixty U.S. Attorneys in that district were nominated by the President and confirmed by the Senate. ${ }^{300}$ This is significant because the U.S. Attorney for the Southern District of New York is widely considered to be the most important U.S. Attorney in the Department of Justice.

The tradition of a newly elected President picking his own District Attorney and U.S. marshal began with President Thomas Jefferson in 1801. As Cummings and McFarland note:

The new administration recognized that to win control of the judiciary, so solidly placed in Federalist hands through the appointment of judges, would prove far more difficult than had been the capture of the Presidency and Congress. While Jefferson disapproved any general dismissal of government officers for partisan reasons, he felt something should be done. "The courts being so decidedly federal and irremovable," he wrote, "it is believed that republican attorneys and marshals, being the doors of entrance into the courts, are indispensably necessary as a shield to the republican part of our fellow-citizens." 301

Accordingly, President Jefferson, for example, appointed Edward Livingston, a signer of the Declaration of Independence, to replace Richard Harrison as the second District Attorney for the District of New York in 1802. ${ }^{302}$ Every permanent U.S. Attorney from 1789 to 2019 has been treated as a superior officer nominated by the President and confirmed by the Senate.

It is a matter of common knowledge that U.S. senators care a great deal about who is the U.S. Attorney in their home state, and Presidents negotiate with care with the relevant state's senators before Presidents nominate some-

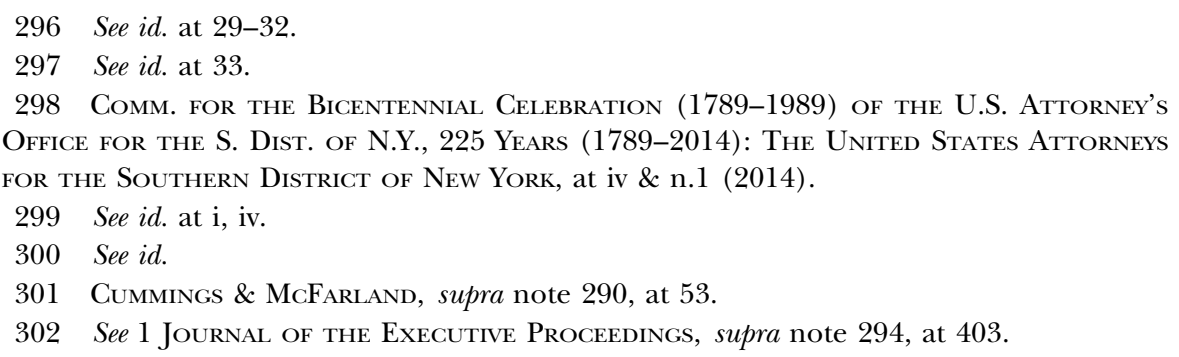


one to be a U.S. Attorney. We think the Senate would find the view, expressed by one district court judge, ${ }^{303}$ that the Attorney General can just appoint ninety-three inferior officer equivalents to U.S. Attorneys and thus bypass the nomination and advice and consent functions of the President and the Senate to be absolutely absurd given the ramifications this would have for federalism, for the separation of powers, and for the protection of civil liberties.

There is no direct caselaw for the proposition that deputy and assistant cabinet secretaries and permanent U.S. Attorneys are superior officers. But neither is there caselaw (one hopes) for the proposition that the sky is blue. The United States Code has consistently been so clear in providing that deputy and assistant cabinet secretaries and permanent U.S. Attorneys are superior officers that no one has ever had occasion to litigate the matter.

It is true that since 1863 interim U.S. Attorneys have been treated by statute as inferior officers appointed by local district courts. ${ }^{304}$ One might therefore try to analogize special counsels to interim U.S. Attorneys-or even to extend that doctrine to conclude that permanent U.S. Attorneys are inferior officers. Indeed, judicial and OLC opinions have on occasion erroneously referred to U.S. Attorneys as being inferior officers, based at least in part on the history of interim U.S. Attorneys. ${ }^{305}$ Both moves should be fiercely resisted.

We have grave doubts about the constitutionality of the present provision for appointment of interim U.S. Attorneys. The provision for court appointment of interim U.S. Attorneys originated in 1863, as part of a short bill for improving the "efficiency"-in the midst of a war-of the judicial department. ${ }^{306}$ We can find no relevant legislative history regarding this provision, which has been carried forward since 1863 without reexamination, except for one brief period early in this millennium. In 2005, the USA PATRIOT Improvement and Reauthorization Act removed the courts from the process of appointment for interim U.S. Attorneys, allowing only the Attorney General to make interim appointments and placing no time limit on how long the interim appointees can serve (though forbidding the Attorney General from appointing anyone who the Senate had previously rejected). ${ }^{307}$ In 2007, in the wake of controversy (whether real or contrived is irrelevant to this point) about the second Bush administration's hiring and firing of U.S. Attorneys, the law was amended to its present form. ${ }^{308}$ We can

303 See In re Grand Jury Investigation, 315 F. Supp. 3d 602, 642 (D.D.C. 2018), aff'd, 916 F.3d 1047 (D.C. Cir. 2019).

304 See 28 U.S.C. $\$ 546$ (d) (2012).

305 See, e.g., United States v. Gantt, 194 F.3d 987, 999 (9th Cir. 1999) ("Because United States Attorneys are 'inferior' officers, $§ 546$ (d) passes constitutional muster.”).

306 See Act of Mar. 3, 1863, ch. 93, § 2, 12 Stat. 768, 768.

307 See USA PATRIOT Improvement and Reauthorization Act of 2005, Pub. L. No. 109177, § 502, 120 Stat. 192, 246 (2006) (codified at 28 U.S.C. $§ 546$ ).

308 See Preserving United States Attorney Independence Act of 2007, Pub. L. No. 110 $34, \S 2,121$ Stat. 224, 224 (codified at 28 U.S.C. $\$ 546$ ). 
find no express discussion of the Appointments Clause issue in the legislative history of that 2007 amendment, although Representative James Sensenbrenner issued a short separate statement indicating that the 2005 amendment had been added "to correct a flaw in the law that permitted the judicial branch to appoint U.S. Attorneys." 309 There is also a footnote in the main report that reminds us that U.S. Attorneys were not subject to the direction of the Attorney General until 1870. ${ }^{310}$ Before that, they were answerable only to the President, which means that in 1863 , there is no doubt at all that they were superior officers.

We understand why a Congress in the midst of a civil war in 1863, in an era without ready means of travel or instantaneous communication, might find it convenient to allow on-the-spot judges to appoint U.S. Attorneys, perhaps even on or near the front lines of battle on short notice, without involving the President or the Senate. But understanding it does not make it constitutional. U.S. Attorneys, whether permanent or interim, have the power to deprive people of life, liberty, or property. The powers to convene grand juries and direct the issuance of subpoenas and indictments are enormous powers. There is nothing inferior or minute about that authority-and we explain in the next section why the extent of an officer's authority is crucial to understanding whether the officer is superior or inferior. However convenient it might be to allow appointment of prosecutorial officers by judges, officers with the level of power of U.S. Attorneys are superior officers who must be appointed by the President with the advice and consent of the Senate. We can perhaps excuse the Congress of 1863 for overlooking this point. We would hope that modern Congresses (and executives and courts) in times of peace can do better.

Even if one accepts the precedent of interim U.S. Attorneys being appointed as inferior officers, that should not in any way color one's judgment about permanent U.S. Attorneys or special counsels. From 1789 to 2019-for a period of 230 years-noninterim U.S. Attorneys have always been treated as superior officers of the United States. That is because they are in fact, and always have been in fact, superior officers of the United States. Special counsels who exercise the same power as U.S. Attorneys are also superior officers for exactly the same reasons. We now turn to this crucial point that far too many modern courts do not seem to grasp.

\section{B. U.S. Attorneys, and Special Counsels, Exercise Too Much Power to Be Considered Inferior Officers}

When one says that a particular actor is "inferior" in an organizational hierarchy, one can mean either or both of two things. First, one can mean that there is someone higher than the actor within the organizational hierarchy-someone who can review and, if necessary, overrule the actor's decision. This is how the Constitution uses the term "inferior" in connection

309 H.R. REP. No. 110-58, at 19 (2007).

310 See id. at 3 n.6. 
with the federal courts. Courts of appeals and district courts (and, we believe, state courts when Congress so designates them) are "Tribunals inferior to the supreme Court." 311 This inferiority is a decisional inferiority-the Supreme Court can review and control the decisions of inferior tribunals. ${ }^{312}$ As the Supreme Court, in an opinion by Justice Scalia, recognized in 1997 in Edmond $v$. United States, ${ }^{313}$ this notion of decisional hierarchy plays an important role in the Appointments Clause as well:

Generally speaking, the term "inferior officer" connotes a relationship with some higher ranking officer or officers below the President: Whether one is an "inferior" officer depends on whether he has a superior. ... [W]e think it evident that "inferior officers" are officers whose work is directed and supervised at some level by others who were appointed by Presidential nomination with the advice and consent of the Senate. ${ }^{314}$

If this account in Edmond is taken as the full specification of inferior officer status, then special counsels under the Reno Regulations would clearly be inferior officers, as special counsels operate under the supervision of the Attorney General. On that reasoning, however, U.S. Attorneys would also be inferior officers, as they also are hierarchically inferior to the Attorney General. So would be Assistant Attorneys General, the Solicitor General, the Deputy Attorney General, and every other person in the Department of Justice other than the Attorney General. The same analysis would apply to every government agency, as every person who is not at the very head of the agency is hierarchically inferior to the person (or, in a multimember commission, the group of persons) at the top of the organization chart. Federal court of appeals judges and district court judges would also be inferior officers, as they are hierarchically inferior to the Supreme Court.

In short, taking this account in Edmond as the exclusive basis for distinguishing inferior from superior officers reduces the latter category to the set of principal officers, with exactly one (or possibly more than one in a multimember commission) noninferior officer in every department or agency of the government. On this reasoning, Congress might choose, as a matter of policy, to have presidential nomination and senatorial consent for additional officers, but the Constitution will require it only for principal officers.

For reasons that we have already given, this is completely ridiculous. It is not a position that can be advanced with a straight face. It makes such spectacular hash of the constitutional structure and constitutional history that we do not believe that anyone seriously advances it (though given the arguments that have recently been made and accepted by lower courts, perhaps that belief is too generous); certainly the U.S. government is not about to argue that everyone in the Department of Justice except the Attorney General is an

\footnotetext{
311 U.S. Const. art. I, § 8, cl. 9.

312 See Steven G. Calabresi \& Gary Lawson, Essay, The Unitary Executive, Jurisdiction Stripping, and the Hamdan Opinions: A Textualist Response to Justice Scalia, 107 Colum. L. REv. 1002, 1016-25 (2007).

313520 U.S. 651 (1997).

$314 I d$. at $662-63$.
} 
inferior officer. And, of course, it was not Justice Scalia's position, nor ours a decade ago, ${ }^{315}$ nor the Constitution's.

The decision in Edmond held that judges on the Coast Guard Court of Criminal Appeals are inferior officers who may be appointed by the Secretary of Transportation. ${ }^{316}$ To show their place in the administrative hierarchy, the majority opinion emphasized the control that could be exercised over those judges "by the General Counsel of the Department of Transportation in his capacity as Judge Advocate General."317 The Judge Advocate General is, of course, not a principal officer in the strict constitutional sense of the term; the Judge Advocate General "in the Coast Guard is subordinate to the Secretary of Transportation." 18 This acknowledges the possibility that Justice Scalia contemplated in his dissenting opinion in Morrison v. Olson in 1988: "To be sure, it is not a sufficient condition for 'inferior' officer status that one be subordinate to a principal officer. Even an officer who is subordinate to a department head can be a principal officer." ${ }^{19}$ Justice Scalia here was using the term "principal officer" to mean what we call a "superior officer"-which clearly acknowledges that there can be superior officers who are not constitutionally principal officers or (what amounts to the same thing) heads of departments.

So if an officer, such as the Judge Advocate General of the Coast Guard, can be a superior officer while still answering to someone else in the organizational hierarchy (in this case the Secretary of Transportation), what makes them superior and the Coast Guard Court of Criminal Appeals judges inferior?

The answer is that there is a second possible meaning of "inferior" in the context of the Appointments Clause and thus two distinct constitutional paths to being a superior officer. One is recognized by Edmond: an officer who does not answer to anyone in the executive hierarchy other than the President is, by definition, a superior officer, as there is no one to whom they can be inferior. That is why officials such as the judges on the Patent Trial and Appeal Board are superior officers; there is no internal executive review of their decisions, which represent the final word in the executive department. ${ }^{320}$ On some occasions, one can therefore determine superior officer status simply by examining the executive hierarchy. One might even be able to determine inferior officer status in many cases through the same hierarchical examination. An officer who is buried beneath many layers of supervisory review is very unlikely to bear any label other than inferior officer.

But there is another understanding of inferiority, and thus another path to superior officer status that can exist even if the officer answers to someone

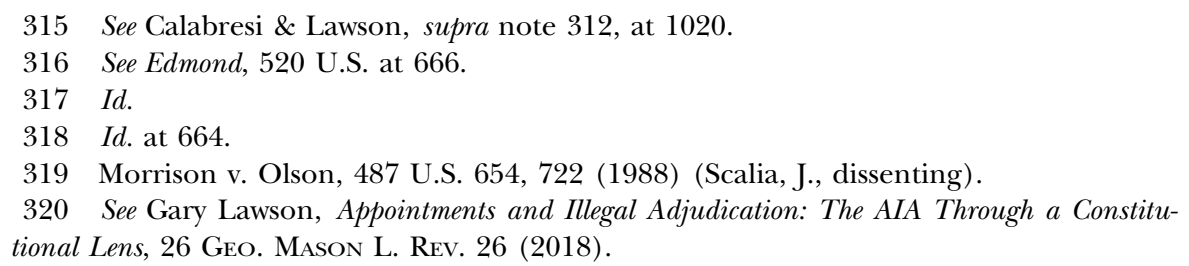


else in a hierarchy. It is true that one meaning of "inferior" in the Appointments Clause-as well as in the Tribunals Clause ${ }^{321}$ and Article III ${ }^{322}$ describes the relationship of one authority to another in a hierarchical chain of command. But that is not the only way in which the term "inferior" was used during the founding era regarding the authority of government officials. For example, in the late eighteenth century, a court whose decisions were not subject to review by any other court could nonetheless sometimes be called an "inferior court" if its jurisdiction or geographic scope was not as extensive as those of other courts, and those courts with broader authority would therefore be "supreme" even if they had no control over the decisions of the "inferior" courts. ${ }^{323}$ Many states during the founding era had exactly this kind of nonhierarchical court system in which courts labeled "supreme" did not necessarily have ultimate review authority over "inferior" courts but simply had wider and broader jurisdiction. ${ }^{324}$ This is why an early draft of Article III at the Constitutional Convention proposed creating "one or more supreme tribunals," 325 recognizing that one could have coexisting "supreme" authorities. "Inferior" does not exclusively mean "subject to control, direction, and review." It means that much, to be sure, but it can also mean more in certain contexts.

As Justice Souter perceptively wrote in his concurring opinion in Edmond:

Because the term "inferior officer" implies an official superior, one who has no superior is not an inferior officer. ...

It does not follow, however, that if one is subject to some supervision and control, one is an inferior officer. Having a superior officer is necessary for inferior officer status, but not sufficient to establish it. ${ }^{326}$

The additional element is the importance and power of the office.

It has been the longstanding practice of Congress and the executive department to recognize superior officer status for all important and powerful public officials even if they have a boss who can fire them. Cabinet secretaries, of course, have always been treated as being superior (and indeed principal) officers even though they can be fired by the President. More to the point, deputy and assistant cabinet secretaries, ambassadors, the Deputy Attorney General, the Solicitor General, and permanent U.S. Attorneys are all superior officers who must be nominated by the President and confirmed by the Senate, even though they can be supervised, directed, and fired by the

321 See U.S. Const. art. I, $\$ 8$, cl. 9 (giving Congress power to "constitute Tribunals inferior to the supreme Court").

322 See id. art. III, $\$ 1$ (vesting the judicial power "in one supreme Court, and in such inferior Courts as the Congress may from time to time ordain and establish").

323 See David E. Engdahl, What's in a Name? The Constitutionality of Multiple "Supreme" Courts, 66 Ind. L.J. 457, 466-72 (1991).

324 See id. at $468-72$.

3252 Records of the Federal Convention, supra note 72, at 21.

326 Edmond v. United States, 520 U.S. 651, 667 (1997) (Souter, J., concurring in part and concurring in the judgment). 
cabinet secretary to whom they report, as well as by the President. The Solicitor General, for example, answers to the Attorney General, who is "the head of the Department of Justice," 327 and can displace or direct the Solicitor General in the representation of the United States. ${ }^{328}$ But given the Solicitor General's baseline power to supervise the conduct of litigation on behalf of the United States, it seems obvious that he or she is a superior officer notwithstanding the hierarchical superiority of the Attorney General. The same is true, for the same reasons, of the Deputy Attorney General and the Assistant Attorneys General and, we believe, of U.S. Attorneys as well. They have this status, as a matter both of statutory practice and of constitutional command, because the importance and power of the office to which they are appointed is so great. It is unthinkable that, for example, the Deputy Secretaries of State or of Defense or the Deputy Attorney General or Solicitor General could be appointed as inferior officers. These officials simply exercise too much power to be denominated inferior officers, even though they are supervised and directed by a higher-ranking officer. They are superior officers, who must be nominated by the President and confirmed by the Senate.

Turning to the federal judiciary, we find that U.S. court of appeals judges and U.S. district court judges have always been treated as being superior officers even though their decisions could be overruled by the Supreme Court. No one thinks or should think that Congress could vest in the Supreme Court the power to appoint lower-court judges as inferior officers. It is obvious that lower-court judges must be superior officers nominated by the President and confirmed by the Senate. Even though they are lower than another body in an organizational hierarchy, their powers are so large that they cannot be considered inferior officers.

The point can be generalized at a more abstract level: the functions performed by an appointee have two distinct layers of constitutional significance. One is to determine whether the appointee is an "Officer of the United States." The duties must rise to some level of importance- "significant authority" according to Buckley $v$. Valeo, ${ }^{329}$ nontriviality according to Professor Mascott-or the appointee is an employee rather than an officer. But once one has met the threshold for being an officer, the significance of the functions has a second potential impact: highly significant functions can make one a superior officer. There is little caselaw on this dimension of superiority and inferiority, for the simple reason that Congress is typically reluctant to cede away the Senate's confirmation power for officers who exercise substantial enough power to raise a constitutional issue-which itself is sufficient reason to doubt whether 28 U.S.C. $\$ 543$ or any other statutory provision cedes away that authority for special counsels with the power of Robert Mueller in the absence of specific language. The courts have never had to decide whether the Deputy Attorney General, the Solicitor General,

32728 U.S.C. $\$ 503$ (2012).

328 See id. $\$ 518$.

329 424 U.S. 1, 126 (1976). 
the Assistant Attorneys General, and the noninterim U.S. Attorneys are inferior officers, because Congress has never tried to authorize their appointment by any method other than the method appropriate for superior officers. Nor do we have an adjective that we think captures in all settings the level of importance of functions that makes one a superior officer. As we have explained at great length elsewhere, not every constitutional norm can be reduced to a clear bright-line rule; there are contexts in which the Constitution prescribes standards rather than rules. ${ }^{330}$ Standard-like norms prescribed by the Constitution are still constitutional norms. If they do not take an aesthetically pleasing form, that is just too bad.

There are, to be sure, lower-court cases holding that interim U.S. Attorneys are inferior officers. ${ }^{331}$ These cases do not explore the issues that we raise here but address only the extent to which U.S. Attorneys are subject to the control and direction of the Attorney General. For example, one court, citing only an 1878 case from the Court of Claims, ${ }^{332}$ asserted "[ $\left.t\right]$ he Constitution does not use the term 'inferior' 'in the sense of petty or unimportant' but in the sense of a subordinate to a principal officer." 333 If taken as a broad generalization, that is flatly untrue, as we have shown. Another case, by the same token, argued that “[a]n officer's status as inferior or principal is not absolute, but relative to those around him. If Congress designs a government position in order to provide a supervisor for a group of officers who formerly were independent, those officers become inferior to the new officer." 334 That is true if the reason why an officer is inferior is grounded in the officer's location within the executive hierarchy. It is plainly not true if the officer's status is determined by the scope of the powers exercised by the officer. The Deputy Attorney General is a superior officer for purposes of the Appointments Clause even if the Attorney General gives one of his or her special assistants an oversight role over the Deputy Attorney General.

In any event, wherever the line between superior and inferior officers is drawn, Assistant Attorneys General and the ninety-three permanent U.S. Attorneys are on the superior side of the line. As we described earlier, ${ }^{335}$ their jobs are so important and powerful that they simply have to be appointed by presidential nomination and senatorial advice and consent.

The same is true of special counsels. Special counsels exercise all the power of a U.S. Attorney. If the latter is a superior officer, so are the former. Senators would (rightly) be furious if the Attorney General appointed inferior officer special counsels to conduct federal prosecutions in their home

330 See Steven G. Calabresi \& Gary Lawson, The Rule of Law as a Law of Law, 90 NotrE Dame L. Rev. 483, 487 (2014).

331 See, e.g., United States v. Hilario, 218 F.3d 19, 25-26 (1st Cir. 2000); United States v. Gantt, 194 F.3d 987, 999 (9th Cir. 1999).

332 Collins v. United States, 14 Ct. Cl. 568, 574 (1878).

333 Gantt, 194 F.3d at 999.

334 Hilario, 218 F.3d at 26.

335 See supra notes 327-28 and accompanying text. 
states, thereby bypassing the confirmation process. It is obvious that a special counsel, like a permanent U.S. Attorney, simply has to be a superior officer.

Consider one example of a special counsel: Robert Mueller. Mueller acted and behaved like a superior officer even though he was never nominated by the President nor confirmed by the Senate. In fact, Mueller was much more powerful than is a permanent U.S. Attorney because he had nationwide jurisdiction and could indict foreign citizens and corporations, ${ }^{336}$ as he did when he indicted more than a dozen Russian citizens and three Russian business entities. ${ }^{337}$ This action had a major effect on our foreign policy with Russia. ${ }^{338}$ Mueller's actual powers are greater than those of a permanent U.S. Attorney and are perhaps more akin to those of an Assistant Attorney General. It is crystal clear that Mueller was a superior officer.

With respect to analogizing special counsels to interim U.S. Attorneys because of the limited duration of their appointments: Robert Mueller served for nearly two years. As Justice Scalia said of Alexia Morrison's equivalent service as an independent counsel, that is "at least as long as many Cabinet officials."339 If one is going to accept the inferior-officer status of interim U.S. Attorneys as a matter of precedent, there is no ground for extending that (misguided) precedent beyond its narrow facts.

We also think we may have been too hasty in earlier proclaiming more than a decade ago that Edmond v. United States overruled Morrison v. Olson sub silentio. ${ }^{340}$ Instead, Edmond added to Morrison the important caveat that one could not be an inferior officer if one did not have a superior. That does not foreclose being a superior officer even if one has a superior. As we said a decade ago:

An officer can be answerable to someone else and yet still be a [superior] officer because of the importance of the scope of the duties, but an officer who does not answer to anyone other than the President is necessarily a principal officer because he or she will be the head of a department. ${ }^{341}$

To be sure, the majority opinion in Morrison $v$. Olson does not leap to our minds as the first place to look for guidance in drawing the line between superior and inferior officers. We have no reason to think that Morrison was asking the right question for this inquiry, much less effectively and dispassionately seeking and reaching the right answers. Nonetheless, for those who care about such things, Morrison was a 7-1 decision of the U.S. Supreme Court that has not formally been overruled in this respect. Accordingly, it is worthwhile (though just barely, according to one of us) to consider how spe-

\footnotetext{
336 See Appointment Memo, supra note 2.

337 See Breslow, supra note 12.

338 Elias Groll, Mueller's Most Lasting Legacy May Be on K Street, Foreign PoL'y (Mar. 28, 2019), https://foreignpolicy.com/2019/03/28/muellers-most-lasting-legacy-may-be-on-kstreet-fara-lobbying-foreign-agents/.

339 Morrison v. Olson, 487 U.S. 654, 718 (1988) (Scalia, J., dissenting).

340 See Calabresi \& Lawson, supra note 312, at 1018.

341 Id. at 1020 (footnote omitted).
} 
cial counsels such as Robert Mueller fare under the inquiry prescribed by Morrison.

\section{Even Under the Test of Morrison v. Olson, Robert Mueller as Special Counsel Is a Superior Officer}

The Morrison $v$. Olson test for officer inferiority held that a statute could not constitutionally interfere with the President's executive power "too much" by giving executive power to so-called inferior officers, thus taking away the President's nomination power. Specifically, Chief Justice Rehnquist said in his majority opinion for the Supreme Court in Morrison v. Olson that four factors must be considered to determine whether an officer can properly be deemed an inferior officer. First, the officer must be removable by a boss. ${ }^{342}$ Second, the officer must perform only "certain, limited duties." 343 Third, the officer must be limited in jurisdiction. ${ }^{344}$ And, fourth, the officer must be given a job with a fixed ending point. ${ }^{345}$

The first part of the Morrison inquiry is close to meaningless if it is taken literally. If being removable by another executive officer makes one inferior, every executive officer except the President and Vice President is inferior. Employees who are in the civil service are harder to remove than officers. We must assume, therefore, that this statement was not meant to be taken literally but rather to focus attention on the degree of control and direction to which an officer is subject, with removal functioning as one mechanism (along with overruling of decisions) for exercising that control and direction. That is why the Court in Edmond interpreted Morrison as meaning "that 'inferior officers' are officers whose work is directed and supervised at some level by others who were appointed by Presidential nomination with the advice and consent of the Senate." 346

But for the same reasons that one cannot literally take removability per se as a mark of inferiority, one cannot literally take the existence of any measure of direction and supervision per se as the mark of inferiority. Otherwise, every officer who is not a principal officer will be inferior. In the context of the Department of Justice, to say that the special counsel is inferior because "governing statutes give the Acting Attorney General broad authority to direct and supervise the Special Counsel" 347 is also to say that the Deputy

\footnotetext{
342 See Morrison, 487 U.S. at 671.

$343 I d$.

344 See id. at 672.

345 See id.

346 Edmond v. United States, 520 U.S. 651, 663 (1997). Nor can one reason from removability by a department head rather than the President to inferior officer status, because that has matters exactly backwards. Who can remove an officer depends on the character of the officer, not vice versa. Congress cannot give the Attorney General power to remove the Secretary of State and thereby make the Secretary of State an inferior officer.

347 In re Grand Jury Investigation, 315 F. Supp. 3d 602, 629 (D.D.C. 2018), aff'd, 916 F.3d 1047 (D.C. Cir. 2019). The district court correctly focused on statutes rather than
} 
Attorney General, the Solicitor General, the Assistant Attorney Generals, and the U.S. Attorneys are inferior officers for the same reasons. The same statutes that give the Attorney General (or acting Attorney General) power to make ultimate decisions within the Department of Justice ${ }^{348}$ apply to those offices as much as they apply to the special counsel. No one has ever thought that Morrison v. Olson, or Edmond v. United States, establishes that there is one and only one noninferior officer in the Department of Justice (and probably in each and every federal department). Rather, the only remotely plausible interpretation of Morrison and Edmond is to say that officers who are subject to a great deal of direction and control are more likely to be inferior than are officers who are subject only to the level of direction and control that is inherent in being anything other than a principal officer. Thus, the Solicitor General is a superior officer because, inter alia, there are very few people in the DOJ who can direct or overrule decisions of the Solicitor General. An assistant U.S. Attorney, on the other hand, can be directed and overruled at multiple levels. In Edmond, the judges of the Coast Guard Court of Criminal Appeals could be directed in various ways by the Court of Appeals for the Armed Forces, ${ }^{349}$ the Judge Advocate General, ${ }^{350}$ and the Secretary of Homeland Security (previously the Secretary of Transportation) who designates the Judge Advocate General of the Coast Guard. ${ }^{351}$ Of course the sheer number of layers of review cannot be dispositive, as the degree of control and direction is also a function of the size and structure of the organization and the overall portfolios of the various officers. But an officer in the Department of Justice who is answerable only to the Attorney General is obviously not inferior.

So how to explain the result in Morrison (without simply dismissing it as absurd)? The Morrison opinion famously said: "We need not attempt here to decide exactly where the line falls between the two types of officers, because in our view appellant clearly falls on the 'inferior officer' side of that line. Several factors lead to this conclusion." 352 Removability was one factor among many, not something that was dispositive. It was factually true that the independent counsel's removability "by the Attorney General indicates that she is to some degree 'inferior' in rank and authority."353 Similarly, the removability of the special counsel indicates that he is "to some degree 'inferior' in rank and authority." 354 The question is whether that degree, and that kind,

regulations as the source of control and direction because any regulations can be altered or repealed by the Attorney General at will. See id. at 627-28; see also United States v. Concord Mgmt. \& Consulting LLC, 317 F. Supp. 3d 598, 615-16 (D.D.C. 2018) (also noting that the regulations can be rescinded).

348 See, e.g., 28 U.S.C. $\$ 509$ (2012).

349 See 10 U.S.C. $\$ 867$ (2012).

350 See id. $\$$ 866; Edmond, 520 U.S. at 664 ("[T]he Judge Advocate General may also remove a Court of Criminal Appeals judge from his judicial assignment without cause.”).

351 See 10 U.S.C. $\$ 801(1)$.

352 Morrison v. Olson, 487 U.S. 654, 671 (1988) (emphasis added).

$353 I d$.

$354 I d$. 
of inferiority is enough to make him an inferior officer under the Appointments Clause. As in Morrison, where the Court did not stop its analysis in its tracks at this mention of removability, one must keep looking at the rest of the picture.

The second part of Chief Justice Rehnquist's four-part test was clearly violated by the Robert Mueller appointment. Robert Mueller was not "empowered ... to perform only certain, limited duties." 355 Whereas the Supreme Court held in Morrison that Alexia Morrison could be a courtappointed independent counsel because she was only prosecuting one former government official, Ted Olson, for two alleged crimes, Robert Mueller investigated alleged criminal activity by the President of the United States, his personal lawyer (whose attorney-client privilege has been breached), and anyone even remotely connected to the President or the President's political campaign. He indicted more than two dozen individuals. He secured guilty pleas in several cases and a guilty verdict in another. The difference between Alexia Morrison's power and Robert Mueller's power could not be starker.

Mueller's appointment violated the second part of the Morrison test by not limiting his office only to certain, limited duties, and it violated the third part of the Morrison test because Mueller's office was not one whose jurisdiction is sufficiently limited. As we have seen, Mueller's jurisdiction extended across the globe and to a dizzying array of persons and alleged crimes. To say, as did one district court, ${ }^{356}$ that Mueller performed only certain, limited duties is akin to saying that General Dwight D. Eisenhower performed only certain limited duties in World War II because he only oversaw the D-Day invasion of France and not the war against the Japanese in the Pacific. As for a fixed end point to Mueller's investigation: the world waited for that for quite some time.

The D.C. Circuit in In re Grand Jury Investigation did not analyze Mueller's appointment under the Morrison test. Instead, drawing on Edmond, it focused on "degree of oversight, final decision-making authority, and removability." 357 The court claimed that any limitations on the Attorney General's supervisory authority contained in regulations were not legally significant because the regulations could always be changed or repealed. ${ }^{358}$ It also noted that the Attorney General can remove the special counsel at any time. ${ }^{359}$ Thus, the court concluded, "[t]he control thereby maintained means the Special Counsel is an inferior officer."360 For the reasons that we have given, a single-minded focus on control and direction leads to the preposterous conclusion that only principal officers are superior officers. The Attorney General cannot remove the Solicitor General, but the Attorney

$355 I d$.

356 See In re Grand Jury Investigation, 315 F. Supp. 3d 602, 640-44 (D.D.C. 2018), aff'd, 916 F.3d 1047 (D.C. Cir. 2019).

357 In re Grand Jury Investigation, 916 F.3d at 1052.

358 See id.

359 See id.

360 Id. at 1053. 
General can control every one of the Solicitor General's actions (and even take them on personally). Does that make the Solicitor General an inferior officer? If the Supreme Court really meant such a thing in Morrison, Edmond, or Free Enterprise Fund, one might have expected a more explicit declaration to that effect. If there are indeed superior officers who are not principal officers-and any other conclusion is absurd-then one needs a subtler analysis than courts seem currently willing to provide.

Control and direction are important to the inquiry whether someone is a superior or inferior officer. An officer who has the last word within the executive department is necessarily superior. But many superior officers are controlled and directed by others. If the lower courts are not going to reason this out for themselves, we urge the Supreme Court to clarify the law. A good start would be to stop calling noninferior officers "principal" officers if they are not heads of departments. This simple linguistic misstep might be doing a grave disservice to the Constitution and the rule of law.

\section{Conclusion}

As we said in the Introduction, there are times when it makes sense to use special counsels. If the high-ranking officials in the Department of Justice would be investigating themselves or their political allies, there is reason to doubt whether they can perform those functions with at least the appearance of objectivity. Special counsels are fine in principle. But there are lawful and unlawful ways to go about creating special counsels.

The Department of Justice should write a new regulation, replacing the 1999 Janet Reno Regulations, specifying that, in the future, special counsels shall be appointed from among the ranks of the permanently appointed U.S. Attorneys. This is an amply large talent pool of superior officers from among whom an appropriately independent special counsel can always be chosen. As we said in the Introduction, just as U.S. Attorney for the Northern District of Illinois, Patrick Fitzgerald, constitutionally prosecuted Scooter Libby in the District of Columbia, so too could acting Attorney General Rod Rosenstein have asked one of the permanent, Senate-confirmed U.S. Attorneys to investigate and prosecute collusion with Russia. Former Attorney General Jeff Sessions asked the U.S. Attorney for Utah, John W. Huber, to investigate alleged wrongdoing by the FBI; and former U.S. Attorney for Maryland, Rod Rosenstein, was asked to investigate alleged leaking in Washington, D.C. by former Attorney General Eric Holder. There is an obviously lawful way to investigate presidential and cabinet-level wrongdoing, and that is by asking a Senate-confirmed permanent U.S. Attorney to undertake the investigation in addition to his other duties.

Our reading of the relevant statutes and the Appointments Clause would allow a future Attorney General to ask any of the existing U.S. Attorneys to serve as a special counsel in a case of alleged presidential wrongdoing. That arrangement is perfectly constitutional. Among that group of ninety-three presidentially nominated and Senate-confirmed personnel one can surely find someone with the intellect, integrity, and character to be a special coun- 
sel as well as a U.S. Attorney. But, importantly for constitutional law purposes, a special counsel who is also a permanent U.S. Attorney is, by the nature of the office, a superior officer nominated by the President and confirmed by the Senate. There was neither the legal authority nor any need to pluck Robert Mueller out of retirement and private life, and make him unconstitutionally one of the most powerful people in Washington. 
